Canadian

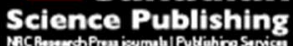

Canadian Journal of Microbiology Revue canadienne de de microbiologie

\title{
Campylobacter species in animal, food and environmental sources and relevant testing programs in Canada
}

\begin{tabular}{|r|l|}
\hline Journal: & Canadian Journal of Microbiology \\
\hline Manuscript ID & cjm-2014-0770.R2 \\
\hline Manuscript Type: & Review \\
\hline Date Submitted by the Author: & 25 -Jun-2015 \\
\hline Complete List of Authors: & $\begin{array}{l}\text { Huang, Hongsheng; Canadian Food Inspection Agency, Ottawa Laboratory } \\
\text { Fallowfield } \\
\text { Brooks, Brian W.; Ottawa Laboratory - Falloefield, Canadian food } \\
\text { Inspection Agency } \\
\text { Lowman, Ruff; Ruff Biosecure Inc, } \\
\text { Carrillo, Catherine D.; Bureau of Microbial Hazards, Health Canada }\end{array}$ \\
\hline Keyword: & $\begin{array}{l}\text { Campylobacter spp., prevalence in animal, food and environment , } \\
\text { Campylobacter testing programs, Canada }\end{array}$ \\
\hline
\end{tabular}

\section{SCHOLARONE" \\ Manuscripts}


1 Campylobacter species in animal, food and environmental sources and relevant testing programs in Canada

4 Hongsheng Huang ${ }^{1}$, Brian W. Brooks ${ }^{1}$, Ruff Lowman ${ }^{2}$ and Catherine D. Carrillo ${ }^{3}$

5 Ottawa Laboratory (Fallowfield), Canadian Food Inspection Agency, 3851 Fallowfield Road,

6 Ottawa, Ontario, Canada ${ }^{1}$, Food Safety Risk Analysis, Food Policy Coordination, Policy and

7 Programs, Canadian Food Inspection Agency, 1400 Merivale Road, Tower 2, Ottawa (Current

8 address: Ruff Biosecure Inc., Ottawa) ${ }^{2}$, Ottawa Laboratory (Carling), 960 Carling Avenue,

9 Canadian Food Inspection Agency, Ottawa, Ontario, Canada ${ }^{3}$

11 Corresponding author: Hongsheng Huang, Ottawa Laboratory (Fallowfield), Canadian Food Inspection

12 Agency, 3851 Fallowfield Road, Ottawa, Ontario, Canada K2H 8P9. Email:

13 Hongsheng.Huang@inspection.gc.ca

14

15

16

17

18 


\section{ABSTRACT}

25 Campylobacter species, particularly thermophilic campylobacters, have emerged as a leading cause

26 of human foodborne gastroenteritis worldwide, with Campylobacter jejuni, C. coli and C. lari

27 responsible for the majority of human infections. Although most cases of campylobacteriosis are

28 self-limiting, campylobacteriosis represents a significant public health burden. Human illness due to

29 infection with campylobacters has been reported across Canada since the early 1970s. Many studies

30 have shown that sources including food, particularly raw poultry and other meat products, raw milk

31 and contaminated water have contributed to outbreaks of campylobacteriosis in Canada.

32 Campylobacter spp. have also been detected in wide range of animal and environmental sources

33 including water in Canada. The purpose of this article is to review the prevalence of Campylobacter

34 spp. in animals, food and the environment, and relevant testing programs in Canada with a focus on

35 potential links of campylobacters with human health in Canada.

36

37 Key words: Campylobacter in animal, food and environment, Campylobacter testing programs, Canada 38 


\section{Introduction}

40 Microaerophilic Gram negative bacteria that are now classified as Campylobacter species were first

41 isolated from samples collected from aborting ewes in 1906 in the United Kingdom (UK) (Skirrow,

42 2006). Since that time, the development and use of selective culture media (Skirrow, 1977; Blaser et

43 al., 1979) has led to the recognition of Campylobacter as a leading cause of human diarrhoeal illness

44 in many countries, including Canada. Campylobacter spp. are commensal organisms in the intestinal

45 tract of a variety of animals including birds, and thus animals are a potential source for

46 contamination of food, water and the environment (Humphrey et al. 2007). Currently, 18 species are

47 recognized in the genus Campylobacter (Debruyne et al. 2008), with additional species including

48 Campylobacter canadensis sp. nov being recently proposed (Inglis et al. 2007). C. jejuni, C. coli and

49 C. lari are responsible for the majority (95\%, 4\% and less than $1 \%$ respectively) of the human

50 gastrointestinal-related Campylobacter infections worldwide (Moore et al. 2005). Other species

51 including C.fetus, C. hyointestinalis, C. upsaliensis and C. sputorum have also been recognized as

52 causal agents of human gastroenteritis (Humphrey et al. 2007) and prenatal infection (Simor et al.,

53 1986), and C. rectus, $C$ gracilis, C. concisus, C. curvus, and $C$. showae as pathogens responsible for

54 human periodontal disease or abscesses (Humphrey et al. 2007).

56 Most cases of campylobacteriosis are self-limiting; however, some infections require hospitalization,

57 and may lead to death and life-threatening post-infection sequelae. Gastroenteritis due to C. jejuni is

58 recognized as the most common antecedent infection associated with Guillain-Barré Syndrome, an

59 acute peripheral demyelinating polyneuropathy causing limb weakness and, in severe cases, total

60 paralysis (Rees et al. 1995). Campylobacter infections, particularly those caused by C. jejuni and

61 infrequently by $C$. coli, have been linked to reactive arthritis and other reactive musculoskeletal 
62 symptoms, enthesopathy or bursitis, postinfectious irritable bowel syndrome and abortion (Blaser

63 and Engberg, 2008). C. jejuni infection may occasionally cause meningitis in infants (Goossens et al.

64 1986), and C. jejuni bowel infection can rapidly lead to fatal myocarditis (Pena and Fishbein, 2007).

66 Campylobacter infections are classified as notifiable diseases and are recognized as the leading

67 bacterial cause of human enteric infections in all provinces and territories in Canada (Public Health

68 Agency of Canada, 2009a; Rajda and Middleton, 2006; Thomas et al. 2013). From 2001 to 2004,

6932,702 cases of campylobacteriosis were reported in Canada with an average of 34.9 cases per

70100,000 population (Ruzante et al. 2011). Similar to other developed countries, campylobacteriosis

71 in Canada peaks in the summer months (June to September), with lowest numbers reported in

72 February and March (Keegan et al. 2009; Lal et al., 2012; Public Health Agency of Canada, 2009a).

73 C. jejuni is the most frequently isolated Campylobacter spp. in Canadian human clinical samples,

74 with $C$. coli being the second most common and C. upsaliensis, C. fetus and C. lari isolated only in a

75 small number of cases (Bowman et al., 2003; Public Health Agency of Canada, 2009a). The

76 predominant identification of $C$. jejuni in Canadian human clinical samples may reflect bias in the

77 microbiological methods used for isolation (Lastovica, 2006), which may have led to false-negative

78 results for cases of human campylobacteriosis. However, a study by Inglis et. al. (2011), conducted

79 in Alberta, found that while current methods did underestimate the presence of other species of

80 Campylobacter, these species were observed in both healthy and diseased individuals and only C.

81 jejuni and C. coli were significantly associated with diarrheic individuals.

82

83 Most cases of human campylobacteriosis in Canada and internationally are sporadic. According to a

84 report of the National Enteric Surveillance Program (NESP), which collects and reports the national 
85 incidence of laboratory confirmed enteric disease cases in Canada (Public Health Agency of

86 Canada, 2011a), for the period between 2000 and 2004, 99.8\% of the total (8353) confirmed

87 Campylobacter cases were sporadic with only 177 cases related to 11 outbreaks and case clusters

88 (Public Health Agency of Canada, 2009a). An investigation of 138 outbreaks of campylobacteriosis

89 in Canada between 1978 and 2005 found that most were associated with poultry (56\%) and dairy

90 products (25\%) (Ravel et al. 2009). Waterborne outbreaks due to Campylobacter spp. have also

91 been reported in Canada, with the largest outbreak occurring in May 2000 in Walkerton, Ontario

92 (Public Health Agency of Canada, 2000; Hrudey et al., 2003; Schuster et al. 2005; Clark et al.

93 2003).

94

95 The purpose of this article is to review the prevalence of Campylobacter spp. in animals, food and

96 the environment, and the relevant testing programs in Canada with a focus on the potential links

97 between sources of campylobacters and human health. The review will provide useful information

98 for further coordinated studies to determine prevalence and baseline levels of this organism

99 throughout the country. A review of the extensive Canadian studies with investigation of

100 Campylobacter epidemiology, basic bacteriology and pathogenesis at the cellular and molecular

101 levels and antimicrobial resistance is beyond the scope of this article.

102

103 Overview of testing programs for campylobacters in food and related

104 sources in Canada

106 According to Raji et al. 2007, Canada's vision for the agri-food industry in the 21st century is the

107 establishment of a national food safety system employing hazard analysis and critical control point 
108 (HACCP) principles and microbiological verification tools, with traceability throughout the gate-to-

109 plate continuum. Voluntary on-farm food safety programs, based in part on HACCP principles,

110 provide producers with guidelines for good production practices focused on general hygiene and

111 biosecurity. Mandatory HACCP programs in federal meat facilities include microbial testing for

112 generic Escherichia coli and specific testing of ground meat for E. coli $\mathrm{O} 157: \mathrm{H} 7$ and raw products

113 for Salmonella (Raji et al. 2007). In Canada, there have been no mandatory federal or national

114 policy and testing programs for campylobacters in food or food animals, water or the environment,

115 however, there have been studies by provincial and federal governments and academics to

116 determine the prevalence of campylobacters in food and related sources. In several provinces

117 including Alberta, Ontario and Quebec, efforts have been made to determine the prevalence of

118 campylobacters in poultry farms and products, and risk factors associated with Campylobacter

119 contamination of various sources (Arsenault et al. 2007a, 2007b and 2007c; Bohaychuk et al. 2006,

120 2009a, 2009b, and 2011; Johnson et al. 2003; Ministry of Ontario Agriculture, Food and Rural

121 Affairs, 2004). FoodNet Canada (formerly known as C-EnterNet) is a multi-partner initiative

122 facilitated by the Public Health Agency of Canada to support activities that will reduce the burden

123 of enteric diseases in humans, by comprehensive sentinel site surveillance and testing for pathogens

124 in potential sources including retail foods, agriculture operations and local water sources (Public

125 Health Agency of Canada, 2014). Currently, there are three sentinel sites within the program, one in

126 each of the provinces of Ontario, British Columbia and Alberta. A national Canadian Integrated

127 Program for Antimicrobial Resistance Surveillance (CIPARS) was established in 2002 by the

128 Public Health Agency of Canada in collaboration with Health Canada, the Canadian Food

129 Inspection Agency and provincial partners (Public Health Agency of Canada, 2011b). This program

130 monitors trends in antimicrobial use and antimicrobial resistance in selected bacterial organisms 
131 including campylobacters from human, animal and food sources across Canada. A pilot study

132 examining antimicrobial resistance in human Campylobacter isolates from Saskatchewan was

133 initiated in 2005.

135 Since the 1980 s, there have been many ad hoc studies of different scales to determine the

136 prevalence of campylobacters in food, food animals, water and the environments in Canada.

137 However, the testing methods, seasons of the year, sampling size, sample type, geographic location,

138 and sampling methods varied greatly between these studies. Thus the wide range of results between

139 studies is difficult to compare and interpret. Nevertheless, the results obtained from these studies

140 provide useful information regarding the distribution of campylobacters in Canada, and form a

141 basis for further coordinated studies to determine prevalence and baseline levels of this organism

142 throughout the country. Recently, a Pathogen Reduction Initiative was established by federal,

143 provincial and territorial governments in Canada, to reduce the four main foodborne bacterial

144 pathogens in meat, including campylobacters in chickens (Canadian Food Inspection Agency,

145 2012). The first task of the initiative has been to establish a national baseline of the four key

146 pathogens in meat and poultry, including Salmonella and Campylobacter in raw chicken, E. coli

147 O157:H7 in raw ground beef and trim, and Listeria monocytogenes in ready-to-eat meats. Since

148 poultry has been shown to be an important source of campylobacters for human infection,

149 nationwide coordinated baseline surveys for poultry will facilitate the implementation of control

150 and prevention programs in Canada.

\section{Campylobacters in animals}

153 Due to the fastidious nature of Campylobacter organisms, propagation generally occurs only within 154 animal hosts, where optimal temperature $\left(37\right.$ to $\left.43^{\circ} \mathrm{C}\right)$ and microaerobic environments favour their 
155 growth (reviewed in Moore et al. 2005). For in vitro isolation, this organism requires modified

156 atmospheric conditions, a longer growing time relative to other enteric pathogens, a narrow temperature

157 range, and specialized media. Campylobacters are commensal colonizers of almost all bird and

158 mammal species investigated, including farm animals, pets and wildlife. Most cases of human

159 illness due to Campylobacter infection are likely to be attributed to poultry (Nadeau et al. 2002;

160 Ravel et al. 2009, Wingstrand et al. 2006). The $42^{\circ} \mathrm{C}$ body temperature of poultry is closest to the

161 optimal growth temperature of the thermophilic campylobacters most frequently associated with

162 disease. Zoonotic Campylobacter reservoirs are important sources of contamination for food (meat,

163 produce), water and the environment (Silva et al. 2001).

164

165 Farmed species.

166 Campylobacter species have been identified in all types of farm animals that have been investigated

167 in Canada. Residents or workers on farms or living in proximity to high densities of farm animals

168 including cows, pigs and chickens or in rural and agricultural areas have a higher incidence of

169 campylobacteriosis than that among rural non-farm or urban residents in Canada, indicating the

170 potential risk of campylobacters in animals to human health (Thompson et al., 1986; Green et al.,

171 2006; Ellis et al. 1995; Levallois et al. 2013).

172

173 Cattle and sheep. Campylobacter spp. have been frequently detected in fecal or tissue samples of

174 Canadian cattle at the farm level in studies conducted from to present (Table 1). The prevalence in

175 cattle ranges between 19 and 93\% using cultural methods, and between 21 and 90\% with culture-

176 independent PCR methodology (Table 1). While C. jejuni and C. coli were reported to be the

177 dominant species in cattle manure in most of the culture-based studies (Munroe et al. 1983; 
178 Waltner-Toews et al. 1986; Van Donkersgoed et al., 1990b; Inglis et al., 2006; Van Donkersgoed

179 et. al. 2009; Hannon et al. 2009a), studies using culture-independent methods indicate that $C$.

180 lanienae is the dominant species (Inglis et al., 2003; Inglis et al., 2004; Guevremont et al., 2008).

181 This latter species is currently considered to be an emerging cause of enteritis with unknown

182 significance. Campylobacters were also isolated from cattle undergoing abortion or with mastitis in

183 Saskatchewan, Canada (Van Donkersgoed et al. 1989; Van Donkersgoed et al. 1990b;

184 Gudmundson and Chirino-Trejo, 1993). Studies have shown a link between campylobacters in

185 cattle and human clinical isolates (Garcia et al. 1985; Hannon et al., 2009b; Public Health Agency

186 of Canada, 2000). These studies indicated a role of cattle as a potential source of

187 campylobacteriosis in Canada. Sheep have also been shown to be an important reservoir for

188 campylobacters. (Sutherland et al. 2009) isolated Campylobacter in 8.7\% of 102 feces collected

189 from 10 Ontario sheep farms, and (Scott et al. 2012) isolated campylobacters in 62\% of 275 fecal

190 samples from a total of 51 sheep flocks in Ontario. In another study in British Colombia

191 campylobacters were isolated from 5 of $42(11.9 \%)$ and 3 of 13 (23.1\%) of domestic sheep and

192 goats respectively (Jokinen et al. 2010).

193

194 Poultry. As in other countries, poultry is frequently colonized with campylobacters in Canada

195 (Table 2). The last national baseline survey of poultry, conducted from 1983 to 1986, found

196 Campylobacter in $73.7 \%$ and $38.2 \%$ of turkey and chicken carcasses, respectively (Lammerding et al.

197 1988). Estimates of the current prevalence of campylobacters in poultry flocks are based on results

198 of provincial baseline surveys and smaller Canadian studies. Overall the results of these studies are

199 variable, with prevalence in poultry flocks between 10 and $88 \%$ (Table 2) with the exception of one

200 survey of poultry fecal samples where no Campylobacter was detected (Public Health Agency of 
201 Canada, 2011c). In addition, a recent study showed that 50\% of 10 production lots from 6

202 organically raised chicken production units were positive for C. jejuni in Quebec (Thibodeau et al.

203 2011) suggesting a prevalence similar to that of a conventional poultry farm. Results from studies

204 using fecal samples from farm or intestinal samples in slaughter houses (Table 2) varied. It is not

205 clear which sampling method would best represent the true prevalence, although studies of feces

206 may under-represent true prevalence due to rapid die-off of campylobacters in this matrix (Shanker

207 et al. 1990). Overall, the variability of results reported between these surveys is likely due to

208 differences in methods used for sampling and microbiological analysis (as discussed at the

209 summary of detection method later on), as well as temporal and geographical factors. Without

210 standardization of methodologies, or regular national baseline surveys, it is difficult to assess

211 whether progress has been made in reduction of campylobacter in this food commodity.

212

213 Swine. Campylobacter spp. are commonly detected in Canadian pigs (Table 3). A nationwide

214 survey (1983-86) indicated a prevalence of 16.9\% (Lammerding et al. 1988). Provincial surveys

215 using culture methods have found prevalence up to 99\% (Mafu et al. 1989; Varela et al. 2007) with

216 C. coli as the most common species detected. Using a PCR method, a survey in Quebec found a

217 prevalence of $25 \%$ (Guévremont et al. 2008) with $40 \%$ for both $C$. lanienae and C. coli among the

218 positive samples (Guévremont et al. 2008). Variability in prevalence appears to be largely

219 associated with source of the samples, with rectal and cecal samples showing higher prevalence

220 than tissue or fecal samples.

221

222 The risk of swine as a source for human campylobacteriosis remains unclear. One investigation in

223 Quebec using pulsed-field gel electrophoresis (PFGE) and phenotypic assay revealed no 
224 epidemiological relationship between isolates from pigs and humans in the same geographic area,

225 suggesting a low risk of contamination of humans by Campylobacter associated with swine

226 production in Quebec (Guévremont et al. 2004). A study in Switzerland showed 1.2\% of 730

227 human campyobacterosis cases were attributed to pigs, although lower than that of 70.9, 19.3 and

$2288 \%$ attributed to chicken, cattle and dogs (Kittl et al., 2013). Further study for a better

229 understanding of the risks of campylobacters from pigs and pork products to human health in

230 Canada is required.

\section{Pets, game and non-farmed species}

234 Dogs. Only a limited number of studies of campylobacters in dogs in Canada have been

235 conducted (Table 4). The prevalence of campylobacters in dogs ranged from 0 to $97 \%$ depending

236 on the study, health status and methods used. Multiple species including C. fetus, C. gracilis, C.

237 helveticus, C. jejuni, C. showae, and C. upsaliensis have been detected in healthy dogs (Chaban

238 et al. 2009; Himsworth et al. 2009). In diarrheic populations, C. coli, C. concisus, C. fetus, C.

239 gracilis, C. helveticus, C. jejuni, C. lari, C. mucosalis, C. showae, C. sputorum and C.

240 upsaliensis have been detected at levels significantly higher than those in healthy dogs (Chaban

241 et al., 2010).

242

243 Game animals. Few studies of Campylobacter species in game animals in Canada have been

244 conducted (Table 4). One study, aimed at investigating the sources of campylobacters on a

245 watershed in British Columbia conducted small scale surveys (5 to 42 samples) of various animals

246 including horses, llamas, alpacas, geese, ducks, cows, chickens, pigs, sheep and goats (Jokinen et 
247 al., 2010). Prevalence of Campylobacter species in these animals ranged from 9-80\%. Typing of 248 animal isolates using flaA gene restriction fragment length polymorphism (RFLP) analysis provided

249 evidence that untreated water, sewage, and some domestic and wild animals share the same flaA-

250 RFLP profiles indicating that campylobacters could spread to multiple domestic and wild animal 251 species sharing the same water source and environment.

253 Aquatic species. Shellfish from contaminated water have been recognized as a source of

254 campylobacters (Moore et al. 2005). Campylobacter spp. were isolated from 47.2\% of $72 \mathrm{Mya}$

255 arenaria clams from the north shore of the St. Lawrence River in Quebec (Lévesque et al. 2006 in

256 Table 4). Contaminated seafood was responsible for $6.3 \%$ of the Canadian campylobacteriosis

257 outbreaks detected between 1976 and 2005 (Ravel et al. 2009). In 262 outbreaks of

258 campylobacterosis reported in USA from 1997 to 2008,12 cases (1.9\%) were due to consumption

259 of seafood (Taylor et al. 2013). Further studies in Canada will be required to identify water sources

260 contributing to higher risk for seafood contamination by campylobacters, and types of seafood with

261 higher risk of causing human campylobacterosis.

263 Wild birds and animals. Wild birds in Canada are frequently colonized with Campylobacter spp.

264 and may play a role in the transmission of this organism to animals and humans by contaminating

265 the environment, feed and food. Campylobacter spp. were isolated from ring-billed gulls (Larus

266 delawarensis) in Quebec, from double-crested cormorant chicks in Prince Edward Island, and from

267 waterfowl including seagulls, Canada geese and ducks in Ontario and British Columbia (Table 4).

268 A novel species (Campylobacter canadensis sp. nov.) was recovered from captive whooping cranes

269 (Grus americana) in Alberta (Inglis et al. 2007). The disease-causing potential of this species 
270 requires further investigation. C. jejuni was not isolated from faecal samples of pronghorn and

271 mule deer in southern Saskatchewan during fall hunting season (Van Donkersgoed et al. 1990a).

272 There have been no other studies to investigate the prevalence of campylobacters in other common

273 wildlife species such as elk and moose in Canada.

275 It is generally believed that wild animals and domestic pets, including dogs, are a potential

276 reservoir of campylobacters for humans (Whiley et al. 2013). A study in Switzerland showed that

$2778 \%$ of 730 human campyobacterosis cases were attributed to dogs (Kittl et al. 2013) and one of 262

278 outbreaks of campylobacterosis reported in USA from 1997 to 2008 was due to contact with kittens

279 (Taylor et al. 2013). A recent study in USA established a laboratory-confirmed link between a

280 campylobacterosis outbreak in human and consumption of contaminated raw peas with birds as a

281 source of produce contamination (Gardner et al. 2011; Kwan et al. 2014). Although the above

282 indicates generally low risks of non-farmed animals and wildlife as a source of campylobacters for

283 humans, the role of migratory birds and wild animals in transmission of pathogenic campylobacters

284 to humans in Canada requires further investigation.

286 Campylobacters in the environment including water

287 Campylobacteriosis in Canada is commonly associated with contaminated water. A review of

288 waterborne outbreaks occurring between 1974 and 2001 in Canada indicated that among 150 of 288

289 outbreaks when a single causative agent was identified, 24\% were caused by Campylobacter

290 (Schuster et al. 2005). The waterborne Campylobacter-associated enteritis outbreaks included: 1) 6

291 patients infected with C. jejuni in a small rural community of Quebec in 1987 due to the

292 consumption of unfiltered and unchlorinated potable water (Alary and Nadeau, 1990), 2) a large 
293 outbreak with 45 laboratory-confirmed and 241 suspected cases in Ontario in 1985 due to the

294 contamination of well water by spring run-off and heavy rains (Millson et al. 1991), 3) an outbreak

295 in Walkerton, Ontario in May 2000, due to the contamination of well water serving the town by

296 surface water carrying livestock waste immediately after heavy rains that resulted in an estimated

297 2,300 illness (167 cases confirmed as E. coli O157:H7 and 116 cases confirmed as Campylobacter

298 spp.) (Public Health Agency of Canada, 2000; Hrudey et al. 2003; Schuster et al. 2005).

300 Several recent Canadian studies have further indicated that the contamination of water at different

301 locations and seasons by campylobacters is common in Canada. These studies at different scales

302 with numbers of samples between 42- 2471 using either cultural methods or combination of cultural

303 and molecular (PCR) methods showed prevalences between 0 and $100 \%$ (Table 5). Water can be

304 contaminated from various fecal sources including farm animals, wildlife and humans (Jokinen et

305 al. 2010). A study using a probabilistic estimation model indicated that while cattle are responsible

306 for the largest amount of manure produced and manure from farm animals such as poultry contain

307 higher concentrations of Campylobacter spp. and are likely to contribute significantly to

308 contamination of water in agricultural environments (Dorner et al. 2004). A survey in Quebec

309 (Arsenault et al. 2007a) showed that there were positive associations between the prevalence of

310 intestinal colonization of campylobacters in chickens and turkeys and environmental risk factors

311 such as distance of manure heap from the poultry/turkey houses, and the use of unchlorinated

312 drinking water.

313

314 By examining extreme rainfall and spring snowmelt in association with 92 Canadian waterborne

315 disease outbreaks caused by Campylobacter and two other organisms between 1975 and 2001, 
316 Thomas et al. (2006) suggested that warmer temperatures and extreme rainfall are contributing

317 factors to waterborne disease outbreaks. (Galanis et al. 2014) examined the association between

318 drinking water, agriculture and 2992 cases of sporadic human campylobacteriosis in 2005-2009 in

319 one region of British Columbia (BC), and found that the odds of campylobacteriosis compared to

3204816 other enteric disease controls were higher for individuals serviced by private wells than

321 municipal surface water systems, and the campylobacteriosis risk, compared to other enteric

322 diseases, seems to be mediated by vulnerable drinking water sources and rural factors. These

323 studies indicate that Campylobacter outbreaks in Canada have been associated with inadequate

324 treatment of small water systems. Because Campylobacter prevalence is generally high in surface

325 water, the protection of groundwater and proper treatment of drinking and irrigation water is very

326 important.

328 Contamination of other environmental sources, such as soil, has also been implicated with

329 campylobacteriosis in Canada. (Stuart et al. 2010) reported a large campylobacteriosis outbreak

330 associated with a mountain bike race that took place in muddy conditions in June 2007 in British

331 Columbia. Among 537 racers, 225 had diarrheal illness after the race. Fourteen C. jejuni clinical

332 isolates were obtained and found to be identical by MLST indicating a common source of infection,

333 with contaminated mud identified as the most likely source (Stuart et al., 2010). Campylobacters

334 were isolated from $0-71 \%$ of 44 soil samples in a feedlot environment of Alberta with manure

335 applications in spring and fall (Van Donkersgoed et. al. 2009). Sheep have also been shown to be

336 an important cause for environmental contamination with campylobacters. (Sutherland et al. 2009)

337 isolated Campylobacter with subsequent PCR confirmation in $22.3 \%$ of 279 soil samples, and $8.7 \%$

338 of 102 feces collected from 10 Ontario sheep farms. 
340 These waterborne and environmental-borne outbreaks have shown the need for attention to broad

341 issues of drinking water security and safety management to prevent such tragedies in the future.

342 Special efforts should be taken to avoid contamination of agricultural products, such as vegetables, 343 from irrigation practices.

345 Campylobacters in food

346 Raw and ready-to-eat meat and poultry

347 The prevalence of Campylobacter spp. in raw retail food in Canada is similar to that in other 348 countries including USA, Spain, Ireland and Wales (Park et al. 1981; Park et al. 1983; Bohaychuk

349 et al., 2006; Suzuki and Yamamoto, 2009). Prevalence of Campylobacter spp. in raw retail chicken

350 varied significantly depending on the studies, ranging from $0-83 \%$ (Table 6). Surveys between

3512007 and 2013 in the Waterloo region of Ontario showed a stable prevalence of campylobacters in

352 raw chicken (Public Health Agency of Canada, 2013, Table 6) indicating a consistent source(s) of

353 contamination. Campylobacter jejuni was isolated from one of eight raw beef liver samples, but not

354 from eight pork and eight beef raw meats in a study conducted in Ontario over a 2-year period

355 (Medeiros et al. 2008). Similarly a low prevalence was found in raw veal meat (1/438) in Ontario

356 (Cook et al., 2011), ground beef (1-12.5\%) in Ontario between 2007 and 2009, and 0-18\% in pork

357 chops in Ontario (2006-2009) (Table 6, Public Health Agency of Canada, 2009). In addition, a

358 study using carcass swab samples of cattle and hogs stored in coolers at slaughter houses in Alberta

359 showed low contamination prevalence for cattle (1.5\%) and pig (8.8\%) samples (Bohaychuk et al.,

360 2011). These studies indicate that the prevalence of campylobacters in raw beef and pork at

361 slaughter house and in retail meats is lower than that in fecal samples from cattle and pigs (Table 1 
362 and 3). However, the prevalence in retail chicken meat was similar to that in fecal samples (Table 2

363 and 6), indicating that raw retail poultry meats present a higher risk to humans than beef and pork

364 meats. Campylobacter was not detected in processed, ready-to-eat meat products (Bohaychuk et al.

365 2006; Medeiros et al. 2008).

366

367 A seven-year study in Belgium by (Ghafir et al. 2007) supported the above Canadian results of

368 lower prevalence of Campylobacter on pork and beef compared to poultry meat. Although the reason

369 for a higher load of campylobacters in chicken meat is not well studied, it may be due to the

370 different meat processing procedures between poultry, cattle and pigs, such as the different types of

371 carcass surfaces or techniques influencing the dryness of carcasses (Ghafir et al. 2007; Whiley et

372 al., 2013) or a higher number of organism in chicken intestines and feces. The common

373 association of Campylobacter spp. with poultry products supports studies indicating that the

374 consumption and handling of contaminated poultry meat appears to be the most common risk factor

375 for human campylobacteriosis (Keener et al. 2004; Humphrey et al. 2007).

\section{Raw milk and raw milk cheese}

378 Raw milk continues to be an important source of foodborne campylobacteriosis in Canada. Milk 379 and associated products have been associated with $31 \%$ of 138 campylobacteriosis outbreaks with 380 agent and source identified and occurring in Canada between 1978 and 2005 (Ravel et al., 2009).

381 Particularly between 1996 and 2005, 3.1\% and 22\% of 32 campylobacteriosis outbreaks were due 382 to milk, and dairy products other than fluid milk respectively (Ravel et al. 2009). For example, in 3831980,14 people in Alberta became ill with enteritis caused by C. jejuni after consumption of 384 unpasteurized cow's milk (McNaughton et al. 1982), and consumption of raw milk from goats and 
385 cows was associated with campylobacteriosis in 63 farm residents in Ontario between 1978 and

3861985 (Thompson et al., 1986). In a survey of 1,720 raw milk bulk tanks in Ontario, 8 isolates of

387 Campylobacter spp. (0.5\% of milk samples) were detected (Steele et al. 1997). However in another

388 study, Campylobacter spp. were not isolated from 34 raw milk cheese samples from Ontario, or

389 from 126 cow, sheep and goat milk samples collected from raw milk cheese manufacturers from

390 across Canada (Medeiros et al. 2008). Further work in determining prevalence of campylobacters

391 in raw milk across Canada is necessary to provide useful relevant risk information.

392

393 Produce

394 The prevalence of Campylobacter spp. in fresh produce has not been investigated frequently in 395 Canada (Table 6). Park and Sanders (1992) analyzed 10 types of vegetables taken from farmers'

396 outdoor markets and supermarkets in Ottawa, Ontario for the presence of thermotolerant

397 campylobacters. In this study Campylobacter spp. were isolated from nine samples of spinach,

398 lettuce, radish, green onions, parsley, and potatoes from the outdoor markets, but not from

399 vegetables washed with chlorinated water. A recent follow-up study of 410 samples from the same

400 market found no Campylobacter (Carrillo et al., 2013). In other studies, campylobacters were not

401 isolated from retail vegetables in Ontario (Park and Sander, 1992; Medeiros et al. 2008; Public

402 Health Agency of Canada, 2009b) or Alberta (Bohaychuk et al. 2006).

403

404 The results in the above studies using cultural methods indicate a low prevalence of campylobacters

405 in fresh vegetables in Canada, which is similar to results of other studies in industrialized countries

406 (Jacobs-Reitsma et al. 2008). There has been no report of campylobacterosis in human due to

407 consumption of produce in Canada. This could be due to the difficulty in determining source of 
408 typically sporadic cases of the campylobacteroisis in humans or to difficulties in isolating the

409 organisms that could be stressed in a viable but non-culturable (VBNC) state or dead due to poor

410 survival under unfavourable environmental conditions. Produce-associated outbreaks have been

411 reported in the USA, with 5\% of 262 outbreaks due to produce from 1997-2008 (Taylor et al.

412 2013). Further studies of commonly consumed vegetables with larger sample sizes would be useful

413 to better understand the contribution of produce to campylobacteriosis in Canada. It would also be

414 worthwhile to further investigate procedures for isolation of campylobacters, that are stressed or in

415 the VBNC state in vegetables and fruits in Canada.

\section{Summary of detection and molecular typing methods and testing}

\section{9 programs for Campylobacter spp. in Canada}

\section{Detection methods}

422 Traditionally campylobacters have been detected using culture procedures, and cultural isolation

423 remains the gold standard for confirming the presence of live bacteria in a sample. Molecular and 424 immunological methods, particularly PCR, have also been used for detection of Campylobacter 425 spp. in different sources (Moore et al. 2005). For the culture methods, three types of culture 426 procedures are commonly used: direct plating, enrichment in broth followed by plating on selective 427 agars, and filtration before direct plating or before plating enrichment broths (Corry et al., 1995; 428 Jokinen et al. 2012). Many different culture media are available for the isolation of campylobacters. 429 However, to date there is no generally accepted single 'standard' method of isolating and detecting 430 all Campylobacter species due to different requirements of temperature, microaerobic conditions, 
431 nutrients and susceptibility to selective antibiotics (Corry et al. 1995; Moore et al. 2005). In

432 Canada, an official reference test method for Campylobacter spp. in food published in Health

433 Canada's Compendium of Analytical Methods is currently in place, namely MFLP-46 (Health

434 Canada, 2014) using Park and Sanders enrichment broth followed by selective plating using 435 mCCDA and Preston agars. Another method, the Agriculture and Agri-Food' Canada Food Safety 436 Procedures Manual-10 (FSPM-10) (Agriculture and Agri-Food Canada, 1997) uses Rosef broth 437 followed by plating on Mueller-Hinton Blood agar with antibiotics. Both methods have been used 438 in a number of Canadian surveys (Table 7). Other methods commonly used in Canada and 439 internationally include the International Standard Organisation (ISO) 10272-1:-2006 standard on 440 detection of Campylobacter (International Standard Organisation, 2006) and the method published 441 in the Bacteriological Analytical Manual of the USDA (United States Department of Food and 442 Drug Administration, 2001). Both of these methods enrich samples in Bolton broth followed by 443 plating on mCCDA selective agar, along with a variety of secondary agars. A similar method, MLG 44441.03 published by the USDA Food Safety and Inspection Service (FSIS), uses direct plating on 445 Campy-Cefex agar and enrichment in Bolton broth, with plating of enrichment broths on Campy446 Cefex agar (United States Department of Agriculture, 2014) has recently been used for a baseline 447 survey of poultry coordinated by the Canadian Food Inspection Agency.

449 There were at least 67 published surveys by 2014 in Canada, including either a single publication or 450 continuing multi-year projects such as the surveillance by FoodNet Canada, which is considered as 451 one survey in this review. Among these surveys, 61 primarily used cultural methods (Tables $1-6)$, 4526 primarily used PCR methods, and 2 additional surveys used culture and conventional or real-time 453 PCR methods in parallel (Tables 1, 3, 4 and 5). 
455 The culture methods used in 61 Canadian surveys included 23 surveys using direct plating surveys, 45639 using enrichment followed by selective plating, 1 using either direct or enrichment depending on 457 sample types, and 5 using filtration or centrifugation followed by direct plating or enrichment 458 Eleven different agars were used for direct plating with mCCDA, Campy-BAP and Karmali being 459 used most frequently (Table 7). Among the seven different enrichment broths used, Bolton broth 460 was the most frequently used followed by Rosef, and Park and Sanders broths (Table 7).

462 The significant variability among surveys of the same or similar types of samples (Tables 1 - 6) 463 may in many cases reflect the use of different methods. For example, in a comparative analysis of 464 two methods commonly used in surveillance of poultry samples, the MFLP-46 method using Park 465 and Sanders broth was found to detect 5\% more campylobacters than that by the ISO 10272-1:2006 466 method using Bolton broth (Carrillo et. al., 2014), and it was suggested that the incorporation of the 467 antifungal agent, cycloheximide, in the less sensitive method may be responsible for this difference. 468 There have been a number of reports in Canada indicating that antibiotics in selective media inhibit 469 growth of some Campylobacter species, particularly C. coli (Ng et al., 1985, Brooks et al., 1986; $470 \quad \mathrm{Ng}$ et al., 1988; Carrillo et. al., 2014).

472 Several different selective agars were used for plating after enrichment in Canadian surveys. Due to 473 the different antibiotics used in the various agars, the usage of selective agars would likely have 474 affected the isolation of different species and strains. For example, with addition of $2.0 \mu \mathrm{g}$ of 475 ciproflaxin to mCCDA, (Inglis et al. 2006) demonstrated a 2-fold increase in recovery of C. fetus 
476 from calf fecal samples. The effect of the various selective agars on isolation of different

477 Campylobacter species and strains in Canada needs further investigation.

479 Most Campylobacter surveys across Canada employed an incubation temperature of $42^{\circ} \mathrm{C}$ and 480 microaerobic condition $\left(85 \% \mathrm{~N}_{2}, 10 \% \mathrm{CO}_{2}, 5 \% \mathrm{O}_{2}\right)$, which are commonly used for isolation of 481 thermophilic campylobacters. Occasionally, additional $\mathrm{H}_{2}$ was used for isolation of C. fetus, C. 482 jejuni, C. coli, C. hyointestinalis and C. lanienae in cattle $\left(42^{\circ} \mathrm{C}\right)$, and C. canadensis sp. nov. in 483 whooping cranes at $\left(37 / 42^{\circ} \mathrm{C}\right)$ (Hoar et al. 2007; Inglis et al. 2006; Inglis et al., 2007). In a large 484 scale water study in Canada, (Khan et al. 2013b) also found higher prevalence (60\% of 759 485 samples) when using $37^{\circ} \mathrm{C}$ culture incubation temperature than that $(34 \%)$ at $42^{\circ} \mathrm{C}$, indicating 486 incubation temperatures significantly affected the recovery of various Campylobacter spp.

In addition, campylobacters are remarkably sensitive to environmental conditions, including 489 dehydration, atomospheric oxygen, sunlight and elevated temperature. Therefore, the sampling 490 methods, freshness of samples, and sample transportation and storage conditions could also have a 491 great impact on the recovery of these organisms. In 60 Canadian surveys that employed cultural 492 methods, the protocols for sampling, type and amount and volume of samples, and sample 493 transportation and storage conditions varied. Samples were collected at various times (immediately 494 after slaughter, in field, or in store), in original form or using swabs, transported with or without 495 transport medium at room temperature or on ice, kept at room temperature or refrigerated before 496 testing, or kept for hours or days before testing. For example, among nine published studies using 497 ruminant fecal material for isolation, the samples were collected and transported in Cary-Blair 498 (Munroe et al. 1983; Lefebvre et al. 2006a) or charcoal (Hannon et al. 2009a) medium in three 
499 studies, whereas in six studies, samples were transported as the original material or as swabs

500 without the use of a transport medium (Waltner-Toews et al. 1986; Van Donkersgoed et al. 1990

501 (b); Inglis et al. 2006; Van Donkersgoed et. al. 2009; Sutherland et al. 2009; Public Health Agency 502 of Canada, 2010). In four of these nine studies, samples were transported on ice or at refrigeration 503 temperature (Inglis et al. 2006; Lefebvre et al. 2006a; Hannon et al., 2009a; Public Health Agency 504 of Canada, 2010 and 2011d), while in the other five studies, the samples were shipped at ambient 505 temperature (Munroe et al. 1983) or under non-disclosed conditions (Waltner-Toews et al. 1986;

506 Van Donkersgoed et al. 1990 (b); Van Donkersgoed et. al. 2009; Sutherland et al., 2009). FoodNet

507 Canada surveys also reported negative result for poultry fecal samples in the first year and much 508 lower numbers of positive samples for the second year of the surveillance compared with higher 509 and stable prevalence for chicken meat at the same period of time during, and higher and stable

510 prevalence for the subsequent years conducted by the same program (PHAC, FoodNet Canada 511 annual reports, 2006-2013). The negative or low prevalence results in the first two years for the 512 poultry fecal samples were believed to be due to the dryness of the samples (PHAC 2010). These 513 variations in sampling methods, sample transportation and storage may lead to variable results 514 between studies.

516 Similar to many other bacterial organisms, campylobacters have also been shown to be able to enter 517 a viable but non-culturable (VBNC) state under harsh conditions (Chaveerach et al. 2003; Li et al. 518 2014; Magajna and Schraft, 2015). The VBNC cells are characterized by a loss of culturability on 519 routine enrichment and agar, which impairs their detection by conventional culture techniques 520 (Chaveerach et al. 2003; Li et al. 2014; Magajna and Schraft 2015). This could lead to an 521 underestimation of total viable cells in food and environmental samples. Campylobater in VBNC 
522 state may be still infectious to humans (Oliver, 2010; Li et al. 2014). Therefore, VBNC pathogenic

523 bacteria should be considered a threat to public health and food safety due to their nondetectability

524 using conventional food, water and other environmental testing methods. This issue should be

525 considered for further development of new methods and strategies for testing of campylobacters in 526 food and environment in Canada.

528 Eight surveys employed PCR as a primary tool or in parallel with culture for detection of

529 Campylobacter spp. DNA with 3 surveys using conventional PCR (Inglis et al. 2003; Guévremont

530 et al. 2008; Lefebvre et al. 2006b) and 5 surveys using real-time PCR (Inglis and Kalischuk, 2004;

531 Chaban et al., 2010; Himsworth et al., 2010; PHAC 2010; Van Dyke et al. 2010). An additional 9

532 studies used PCR for confirmation or species identification (Lévesque et al. 2006a; Inglis et al., 533 2007; Jokinen et al., 2010; Sutherland et al., 2009; Leonard et al. 2011; Khan et al. 2013a; Khan et

534 al. 2013b; Schmidt et al. 2013; Khan et al. 2014). In these studies different primers targeting 535 various gene regions were employed. For studies in which PCR and culture were compared, the 536 PCR procedures showed a higher detection rate than the culture procedure (Van Dyke et al. 2010;

537 FoodNet Canada annual reports 2006 and 2007), indicating that detection methods could make a

538 difference in final results particularly when the contamination level is low. In addition, some

539 Campylobacter spp., such as C. lanienae, could not be cultured on commonly used media (Inglis

540 and Kalischuk 2003). PCR methods could potentially be used as rapid, quantitative and universal

541 methods for detection of wide range of Campylobacter spp. However, in most cases, PCR methods

542 do not distinguish between live and dead cell, and likely overestimate prevalence of viable

543 campylobacters. 
545 Most of the studies in Canadian surveys (Tables $1-6$ ) were conducted using available methods

546 without indicating the detection limit and specificity. Only a small number of studies in Canada

547 indicated the detection limit, including those using culture methods (Lammerding et al. 1998; Cook

548 et al. 2012; Schmidt et al. 2013; Khan et al. 2013a and b, 2014; FoodNet Canada annual reports)

549 and those using PCR methods (Inglis et al., 2003 and 2004; van Dyke et al. 2010; Himsworth et al.

550 2010; Chaban et al. 2010). Even for the commonly used methods, different results could be

551 obtained due to the various detection sensitivities when using methods that had not been validated

552 in the original studies. It is difficult to make judgements on the potential false-positive and negative

553 results without knowing the uncertainties of test methods for various types of samples.

555 The use of standard or equivalent methodologies capable of detection of all Campylobacter species 556 with known detection limit for various types of samples is necessary to obtain a clearer picture of 557 the distribution of Campylobacter species in Canadian sources. There is also a need to develop or 558 adopt and validate internationally recognizable or comparable and consistent methods to be used in 559 Canada for rapid detection of thermotolerant campylobacters in foods. To date there is no generally 560 accepted single 'standard' method of isolating and detecting all Campylobacter spp. In recent years, 561 several procedures including immuno-based assays (ELISA, PCR-ELISA) and DNA-based

562 detection methods (conventional and real-time PCR are becoming more widely accepted

563 internationally (Moore et al. 2005 and Humphrey et al. 2007) and in Canada.

\section{Typing methods}


567 A number of subtyping methods have been applied to Campylobacter surveillance in Canada.

568 These have included phenotypic methods (biotyping, serotyping and phage typing), genotypic

569 methods (e.g. PFGE, flagellin-based subtyping and multi-locus sequence typing (MLST)).

570 Currently, the most widely deployed typing method for national surveillance programs is

571 Comparative Genomic Fingerprinting (CGF) (Taboada et al. 2013).

572

573 Valuable information regarding the epidemiology of campylobacteriosis has been obtained by the

574 application of Campylobacter sub-typing methods to isolates from human, animal, food and

575 environmental samples from across Canada. In early studies, two serotyping schemes developed in

576 Canada in the 1980s, namely the Penner scheme based on heat-stable antigens (Penner and

577 Hennessy, 1980) and the Lior scheme based on heat-labile antigens (Lior et al. 1982), were widely

578 used to characterize Campylobacter isolates. Epidemiological linkages between isolates of the same

579 serotype were demonstrated for sporadic cases and outbreaks of human gastroenteritis in Ontario

580 and British Columbia (Karmali et al. 1983; McMyne et al. 1982), and on isolates from cattle and

581 pigs in Ontario (Munroe et al. 1983; Garcia et al. 1985). While serotyping schemes have

582 historically been extremely effective for classification of Campylobacter isolates, more recent

583 studies favor the use of molecular typing methods.

584

585 A number of genotypic subtyping methods have been developed for Campylobacter spp. (reviewed

586 in Humphrey et al. 2007; Taboada et al. 2013). The methods that are most widely used in Canada

587 include: 1) PFGE (e.g., Steele et al. 1998, Nadeau et al. 2002, Clark et al. 2003, Guévremont et al.

$5882004,2014), 2$ ) characterization of the flagellin locus through restriction fragment length

589 polymorphism (flaA-RFLP) or DNA sequencing of the short variable region (flaA SVR) (e.g. Clark 
590 et al. 2005, 2012, Guévremont et al. 2014 ), 3) MLST (e.g., Clark et al. 2005, 2012), and 4) CGF

591 (Taboada et al. 2012; Taboada et al. 2013, Deckert et al. 2014). Heat-stable serotyping and fla-

592 RFLP typing (Clark et al. 2003), and Oxford MLST or flagellin short variable region (fla-SVR)

593 sequencing methods (Clark et al. 2005) helped to identify the Campylobacter spp. outbreak strains

594 and their source for a waterborne disease outbreak in Walkerton, Ontario in 2000. In Canadian

595 studies, the choice of a particular technique has depended to a large extent on the level of

596 discrimination desired (Steele et al. 1998; Guévremont et al. 2004; Clark et al. 2005, Clark et al.

597 2012). The limitation of using different subtyping methods is that data generated using different

598 methods cannot be compared.

600 New methods based on binary typing or comparative genomic analysis (Hannon et al. 2009b; Clark 601 et al. 2012; Taboada et al. 2004, 2012,) are proving to be very useful for both large scale and small

602 scale population typing. The CGF typing scheme has been widely adopted in Canadian surveillance 603 programs (Clark et al. 2012, Taboada et al. 2013, Deckert et al. 2014). The use of this low cost, 604 high throughput methodology has enabled the characterization of thousands of isolates (E. Taboada, 605 personal communication) which can now be analyzed in aggregate, supporting the study of 606 Campylobacter epidemiology in Canada (Clark et al. 2012, Deckert et al. 2014).

608 Recently, whole genome sequencing (WGS) has emerged as a powerful tool for research and 609 diagnostics._WGS data provides the highest levels of discriminatory power for epidemiologic 610 subtyping since single nucleotide differences can be used to distinguish isolates (Carrillo et al., 611 2012; Taboada et al. 2013). In addition, typing data for historical methods such as MLST and flaA 612 SVR can be derived from WGS data in silico enabling comparison to previous studies (Taboada et 
613 al. 2013). Moreover, WGS data generated in different studies can be easily compared at both the

614 national and international level, regardless of methods used to generate sequence data. With

615 decreasing costs, WGS is rapidly becoming a viable option for Campylobacter subtyping.

616

617 Surveillance program in poultry

618 The consumption and handling of contaminated poultry meat seems to be the most common risk

619 factor for human campylobacterosis internationally (Keener et al. 2004; Humphrey et al. 2007) and

620 in Canada (Ravel et al. 2009). Multifaceted intervention approaches are required to successfully

621 control contamination of poultry during the various phases of the growth period and processing

622 procedure of broiler chickens. In recent years, there is an international trend to investigate baselines

623 at raw meat and farm levels to effectively understand the effects of intervention measures. Efforts

624 to eliminate Campylobacter transmission via the food chain or to reduce the prevalence of

625 Campylobacter in poultry slaughter house or flocks have been made internationally (White et al.

626 1997; Moore et al. 2005; Krause et al. 2006). Many countries, such as the European Union (EU)

627 member countries, United States of America, Iceland and New Zealand (European Food Safety

628 Authority, 2010; Stern et al. 2003; Department of Agriculture of United States - Food Safety and

629 Inspection Service (USDA-FSIS), 2008 and 2012; Wagenaar et al. 2013) have conducted

630 coordinated baseline studies. These baseline studies are an important step for designing further

631 reduction measures. Reduction measures in Iceland including freezing carcasses from positive

632 flocks have significantly reduced prevalence in chicken meat and have resulted in a $72 \%$ reduction

633 in cases of human campylobacterosis (Trustin et al. 2011; Wagenaar et al. 2013), In New Zealand,

634 interventions applied to poultry production resulted in a 54\% of decline of human

635 campylobacterosis between 2002 and 2008 (Sears et al. 2011). In 2010, the USDA-FSIS 
636 announced performance standards and a compliance guide for Salmonella and Campylobacter in

637 young chicken and turkey to help the poultry industry address Salmonella and Campylobacter

638 (USDA, 2010). In Canada, there have been no mandatory federal or national policy and

639 testing/control programs for foodborne campylobacters in food or food animals; however, there

640 have been some efforts by federal, provincial or municipal governments as described above (Table

$641 \quad 1-6)$ and baseline surveys of poultry have been recently conducted under pathogen reduction

642 initiatives in Canada. Although HACCP programs have not applied for campylobacters in food

643 programs in Canada, a recent survey in Alberta (Van Donkersgoed et al. 2009) recovered

644 campylobacters from $76 \%$ of cattle manure samples $(1590 / 2100)$ in 21 Alberta feedlots, but only

645 one isolate of Campylobacter (1/1653) from beef carcasses in the cooler following HACCP

646 interventions. These results indicate that HACCP interventions play an important role in controlling

647 the spread of campylobacters during processing of cattle. To date, most of the surveys in Canada

648 used only qualitative isolation methods. More informative Canadian baseline studies and food

649 testing programs would benefit from the application of standardized, simple and rapid quantitative

650 culture (or equivalent) methods.

\section{Summary}

653 Although most cases of gastroenteritis caused by Campylobacter infection are mild and only rarely

654 result in death, campylobacteriosis represents a significant public health burden (Ruzante et al.,

655 2011), with costs high enough to justify prevention efforts. The understanding of the distribution

656 and prevalence of campylobacters in food, animals, water and the environment is a crucial step for

657 prevention. It has been shown that campylobacters are widely distributed in retail meats, domestic

658 and wild animals, poultry, pets, water and soil in Canada. Prevalence does not seem to have 
659 changed significantly since testing programs began in the 1980 s, however, it is difficult to assess

660 changes in prevalence in different sources due to variability of the small scale studies conducted in

661 Canada since this time. There have been a few surveillance studies at the national, provincial and

662 academic levels in Canada, but more data is needed on a national scale, especially in linking

663 clinical and source data. Continued and further coordinated support with consistent and

664 comprehensive schemes for these initiatives is needed. This will greatly enhance the understanding

665 of the epidemiology of these organisms, virulence factors associated with different strains and

666 importantly their traceability. The lack of coordinated national prevalence studies has resulted in

667 reliance on regional investigations that lack consistency in sampling, sample shipping, culture and

668 molecular procedures and consequently a wide range of results across Canada have been reported.

669 Therefore, there is a need to improve, validate and standardize comparable or equivalent methods

670 and protocols according to international requirements and trends to meet different needs of

671 government and industry testing laboratories. There was a paucity of studies in the 1990s during

672 which almost no testing on campylobacters in animals or the environment was reported in Canada

673 (Tables 1, 2, 3 and 5). Therefore, a long term plan should be established for the continuity of

674 monitoring this organism from various sources. Careful and coordinated implementation of studies

675 to detect campylobacters in various sources will enhance understanding of the sources of

676 transmission of these organisms to humans and inform implementation of effective control and 677 preventive measures.

\section{References}

680 Agriculture and Agri-Food Canada.1997. Isolation of thermophilic campyobacters from fresh pork, 681 beef, poultry and ready-to-eat meat products, Chapter 10. In Food safety procedures manual, 
682 version 5.0. Animal and Plant Health Directorate, Food production, and Inpsection Branch.

683 Agriculture and Agri-Food Canada, Ottawa, Ontario.

Alary, M., Nadeau, D. 1990. An outbreak of Campylobacter enteritis associated with a community Arsenault, J., Letellier, A., Quessy, S., Normand, V., Boulianne, M. 2007a. Prevalence and risk factors for Salmonella spp. and Campylobacter spp. caecal colonization in broiler chicken and turkey flocks slaughtered in Quebec. Prev. Vet. Med. 81:250-264.

Arsenault, J., Letellier, A., Quessy, S., Morin, J.P., Boulianne, M. 2007b. Prevalence and risk factors for Salmonella and Campylobacter spp. carcass contamination in turkeys slaughtered in Quebec, Canada. J. Food. Prot. 70:1350-1359.

Arsenault, J., Letellier, A., Quessy, S., Boulianne, M. 2007c. Prevalence and risk factors for Salmonella and Campylobacter spp. carcass contamination in broiler chickens slaughtered in Quebec, Canada. J. Food. Prot. 70:1820-1828.

Bingham, W.T., Chan, A., Rennie, R., Williams, K.E., Sankarna, K. 1992. Neonatal Campylobacter fetus meningitis: a report of an unusual case. Clin. Pediat (Philadelphia). 31:255-256.

Blaser, M.J., Berkowitz, I.D., Laforce, F.M., Cravens, J., Reller, L.B., Wang, W.-L. 1979. Campylobacter enteritis: clinical and epidemiologic features. Ann. Int. Med. 91:179-85.

Blaser, M.J., and Engberg, J. 2008. Clinical aspects of Campylobacter jejuni and Campylobacter coli infections. In Campylobacter, third edition ed. Nachamkin, I., Szymanski, C.M., and Blaser, M.J: ASM Press (Washington). pp: 99-121.

Bohaychuk, V.M., Gensler, G.E., King, R.K., Manninen, K.I., Sorensen, O., Wu, J.T., Stiles, M.E., McMullen, L.M. 2006. Occurrence of pathogens in raw and ready-to-eat meat and poultry products collected from the retail marketplace in Edmonton, Alberta, Canada. J. Food Prot. 69:2176-2182.

Bohaychuk, V.M., Checkley, S.L., Gensler, G.E., Barrios, P.R. 2009a. Microbiological baseline study of poultry slaughtered in provincially inspected abattoirs in Alberta, Canada. Can Vet J. 50:173-178.

Bohaychuk, V.M., Bradbury, R.W., Dimock, R., Fehr, M., Gensler, G.E., King, R.K., Rieve, R., Romero Barrios, P. 2009b. A microbiological survey of selected Alberta-grown fresh produce from farmers' markets in Alberta, Canada. J. Food Prot. 72:415-420.

Bohaychuk, V.M., Gensler, G.E., Barrios, P.R. 2011. Microbiological baseline study of beef and pork carcasses from provincially inspected abattoirs in Alberta, Canada. Can. Vet. J. 52:10951100 .

Boukraa, L., Messier, S., Robinson, Y. 1991. Isolation of Campylobacter from livers of broiler chickens with and without necrotic hepatitis lesions. Avian Dis. 35:714-717. 
Bowman, C., Flint, J., Pollari, F. 2003. Canadian integrated surveillance report: Salmonella, Campylobacter, pathogenic E. coli and Shigella, from 1996 to 1999. Can Com Dis Rep. 29 Suppl 1:i-vi, 1-32.

Brooks, B.W., Garcia, M.M., Fraser, D.E., Lior, H., Stewart, R.B., Lammerding, A.M. 1986. Isolation and characterization of cephalothin-susceptible Campylobacter coli from slaughter cattle. J. Clin. Microbiol. 24:591-595.

Canadian Food Inspection Agency, 2012. Federal/Provincial/Territorial Pathogen Reduction Initiative. http://www.inspection.gc.ca/food/meat-and-poultryproducts/pathogen/eng/1338819927004/1338819992816. Accessed on 2012-06-04.

Carrillo, C.D., Kruczkiewicz, P., Mutschall, S., Tudor, A., Clark, C., Taboada, E.N. 2012. A framework for assessing the concordance of molecular typing methods and the true strain phylogeny of Campylobacter jejuni and C. coli using draft genome sequence data. Front. Cell Infect. Microbiol. 2:article 57.

Carrillo, C.D., Sproston, E., Kenwell, R., Ivanov, N., Phipps Todd, B., Huang, H. 2013. Prevalence of Arcobacter spp. in fresh vegetables from farmers' outdoor markets in Ottawa, Canada. Abstracts of posters and oral presentations from the 17th International Workshop on Campylobacter, Helicobacter and Related Organisms, Aberdeen, Scotland, 15-19th September 2013. http://jmm.sgmjournals.org/content/62/Pt_9/suppl/DC1, p.99.

Carrillo, C.D., Plante, D., Iugovaz, I., Kenwell, R., Bélanger, G., Boucher, F., Poulin, N., Trottier, Y.L.2014. Method-dependent variability in determination of prevalence of Campylobacter jejuni and Campylobacter coli in Canadian retail poultry. J. Food Prot. 77:1682-688.

Chaban, B., Musil, K.M., Himsworth, C.G., Hill, J.E. 2009. Development of cpn60-based real-time quantitative PCR assays for the detection of 14 Campylobacter species and application to screening of canine fecal samples. Appl. Environ. Microbiol. 75:3055-3061.

Chaban, B., Ngeleka, M., Hill, J.E. 2010. Detection and quantification of 14 Campylobacter species in pet dogs reveals an increase in species richness in feces of diarrheic animals. BMC Microbiol.

\section{0:73.}

Chaveerach, P., ter Huurne, A.A.H.M., Lipman, L.J.A., van Knapen, F. 2003.Survival and Resuscitation of Ten Strains of Campylobacter jejuni and Campylobacter coli under Acid Conditions. Appl. Environ. Microbiol. 69:711-714. 
Clark, C.G., Bryden, L., Cuff, W.R., Johnson, P.L., Jamieson, F., Ciebin, B., Wang, G. 2005. Use of the oxford multilocus sequence typing protocol and sequencing of the flagellin short variable region to characterize isolates from a large outbreak of waterborne Campylobacter sp. strains in Walkerton, Ontario, Canada. J. Clin. Microbiol. 43:2080-2091.

Clark, C.G., Taboada, E., Grant, C.C.R., Blakeston, C., Pollari, F., Marshall, B., Rahn, K., MacKinnon, J., Daignault, D., Pillai, D., Ng, L-K. 2012. Comparison of molecular typing methods useful for detecting clusters of Campylobacter jejuni and $C$. coli isolates through routine surveillance. J. Clin. Microbiol. 50:798-809.

Cook, A., Reid-Smith, R., Irwin, R., McEwen, S.A., Valdivieso-Garcia, A., Ribble, C. 2009. Antimicrobial resistance in Campylobacter, Salmonella, and Escherichia coli isolated from retail turkey meat from southern Ontario, Canada. J. Food Prot. 72:473-481.

Cook, A., Reid-Smith, R.J., Irwin, R.J., McEwen, S.A., Young, V., Ribble, C. 2011. Antimicrobial resistance in Campylobacter, Salmonella, and Escherichia coli isolated from retail grain-fed veal meat from Southern Ontario, Canada. J Food Prot. 74:1245-51.

Cook, A., Odumeru, J., Lee, S., Pollari, F. 2012. Campylobacter, Salmonella, Listeria monocytogenes, Verotoxigenic Escherichia coli, and Escherichia coli Prevalence, Enumeration, and Subtypes on Retail Chicken Breasts with and without Skin. J. Food Prot. 75:34-40.

Corry, J.E., Post, D.E., Colin, P., Laisney, M.J. 1995. Culture media for the isolation of campylobacters. Int. J. Food Microbiol. 26:43-76.

Debruyne L., Gevers, D., Vandamme, P. 2008. Taxonomy of the Family Campylobacteraceae. Chapter 1. In: Nachamkin I, Szymanski C, and Blaser M. (Eds.), Campylobacter. ASM Press, Washington DC, USA, pp. 1 - 25.

Deckert, A., Valdivieso-Garcia, A., Reid-Smith, R., Tamblyn, S., Seliske, P., Irwin, R., Dewey, C., Boerlin, P., Mcewen, S.A. 2010. Prevalence and antimicrobial resistance in Campylobacter spp. isolated from retail chicken in two health units in Ontario. J. Food Prot. 73:1317-1324.

Deckert, A., Taboada, E, Mutschall, S., Poljak, Z., Reid-Smith, R., Tamblyn, S., Morrell, L., Seliske, P., Jamieson, F.B., Irwin, R., Dewey, C., Boerlin, P., Mcewen, S.A. 2014. Molecular epidemiology of Campylobacter jejuni human and chicken islates from health units. Foodborne Pathog Dis. 11:150-155.

Dobbin, G., Hariharan, H., Daoust, P.Y., Hariharan, S., Heaney, S., Coles, M., Price, L., Muckle, C.A. 2005. Bacterial flora of free-living double-crested cormorant (Phalacrocorax auritus) chicks on Prince Edward Island, Canada, with reference to enteric bacteria and antibiotic resistance. Comp. Immunol. Microbiol. Inf. Dis. 28:71-82.

Dorner, S.M., Huck, P.M., Slawson, R.M. 2004. Estimating potential environmental loadings of Cryptosporidium spp. and Campylobacter spp. from livestock in the Grand River Watershed, Ontario, Canada. Env. Sci. Tech. 38:3370-3380. 
Ellis, A., Irwin, R., Hockin, J., Borczyk, A., Woodward, D., Johnson, W. 1995. Outbreak of Campylobacter infection among farm workers: an occupational hazard. Can. Comm. Dis. Rep.15:153-156.

European Food Safety Authority. 2010. Analysis of the baseline survey on the prevalence of campylobacter in broiler batches and campylobacter and salmonella on broiler carcasses in the EU. EFSA Journal. 8:1503.

Farzan, A., Friendship, R.M., Cook, A., Pollari, F. 2010. Occurrence of Salmonella, Campylobacter, Yersinia enterocolitica, Escherichia coli $\mathrm{O} 157$ and Listeria monocytogenes in Swine. Zoonoses Public Health. 57:388-390.

Finlay, R.C., Mann, E.D., Horning, J.L. 1986. Prevalence of Salmonella and Campylobacter contamination in Manitoba swine carcasses. Can. Vet. J. 27:185-187.

Galanis, E., Mak, S., Otterstatter, M., Taylor, M., Zubel, M., Takaro, T.K., Kuo, M., Michel, P. 2014. The association between campylobacteriosis, agriculture and drinking water: a case-case study in a region of British Columbia, Canada, 2005-2009. Epidemiol. infect. 142:2075-2084.

Garcia, M.M., Lior, H., Stewart, R.B., Ruckerbauer, G.M., Trudel, J.R., Skljarevski, A. 1985. Isolation, characterization, and serotyping of Campylobacter jejuni and Campylobacter coli from slaughter cattle. Appl. Environ. Microbiol. 49:667-672.

Gardner, T.J., Fitzgerald, C., Xavier, C., Klein, R., Pruckler, J., Stroika, S., McLaughlin, J.B. 2011. Outbreak of campylobacteriosis associated with consumption of raw peas. Clin. Infect. Dis. 53:2632.

857 Gudmundson, J., Chirino-Trejo, J.M.A. 1993. A case of bovine mastitis caused by Campylobacter 858 jejuni. J. Vet. Med. Series B. 40:326-328.

859 Guévremont, E., Higgins, R., Quessy, S. 2004. Characterization of Campylobacter isolates 860 recovered from clinically healthy pigs and from sporadic cases of campylobacteriosis in humans. J. 861 Food Prot. 67:228-234. 
862

863

864

865

866

867

868

869

870

871

872

873

874

875

876

877

878

879

880

881

882

883

884

885

886

887

888

889

890

891

892

893

894

895

896

897

898

899

900

901

902

903

904

905

906

907

908
Guévremont, E., Normand, V., Lamoureux, L., Côté, C. 2008. Genetic detection of Campylobacter lanienae in fecal matter and stored manure from swine and dairy cattle. Foodborne Pathog. Dis. 5:361-364.

Guévremont, E., Lamoureux, L., Loubier, C.B., Villeneuve, S., Dubuc, J. 2014. Detection and characterization of Campylobacter spp. from 40 dairy cattle herds in Quebec, Canada. Foodborne Pathog. Dis. 11:388-94.

Hannon, S.J., Allan, B., Waldner, C., Russell, M.L., Potter, A., Babiuk, L.A., Townsend, H.G.G. 2009a. Prevalence and risk factor investigation of Campylobacter species in beef cattle feces from seven large commercial feedlots in Alberta, Canada. Can. J. Vet. Res. 73:275-282.

Hannon, S.J., Taboada, E.N., Russell, M.L., Allan, B., Waldner, C., Wilson, H.L., Potter, A., Babiuk, L., Townsend, H.G.G. 2009b. Genomics-based molecular epidemiology of Campylobacter jejuni isolates from feedlot cattle and from people in Alberta, Canada. J. Clin. Microbiol. 47:410420.

Hariharan, H., Wright, T., Long, J.R. 1990. Isolation and antimicrobial susceptibility of Campylobacter coli and Campylobacter jejuni from slaughter hogs. Microbiologica. 13:1-6.

Health Canada. 2014. Compendium of analytical methods Volume 3 Isolation of thermophilic Campylobacter from food. MFLP - 46, December 2014. http://www.hc-sc.gc.ca/fn-an/resrech/analy-meth/microbio/volume3/mflp46_e.html.

Health Canada. 2011. Policy on Listeria monocytogenes in Ready-to-Eat Foods (2011).

http://www.hc-sc.gc.ca/fn-an/legislation/pol/policy_listeria_monocytogenes_2011-eng.php. Last accessed on October 15, 2013.

Himsworth, C.G., Skinner, S., Chaban, B., Jenkins, E., Wagner, B.A., Harms, N.J., Leighton, F.A., Thompson, R.C.A., Hill, J.E. 2010. Multiple zoonotic pathogens identified in canine feces collected from a remote Canadian indigenous community. Am. J. Trop. Med. Hyg. 83:338-341.

Hoar, B.M., Whiteside, D.P., Ward, L., Inglis, G..D., Morck, D.W. 2007. Evaluation of the enteric microflora of captive whooping cranes (Grus americana) and sandhill cranes (Grus canadensis). Zoo Biol. 26:141-153.

Hrudey, S.E., Payment, P., Huck, P.M., Gillham, R.W., Hrudey, E.J. 2003. A fatal waterborne disease epidemic in Walkerton, Ontario: comparison with other waterborne outbreaks in the developed world. Water Sci. Technol. 47:7-14.

Humphrey, T., O’Brien, S., Madsen, M. 2007. Campylobacters as zoonotic pathogens: A food production perspective. Int. J. Food Microbiol. 117:237-257.

Inglis GD1, Kalischuk LD. 2003. Use of PCR for direct detection of Campylobacter species in bovine feces. Appl. Environ. Microbiol. 69:3435-47. 
909

910

911

912

913

914

915

916

917

918

919

920

921

922

923

924

925

926

927

928

929

930

931

932

933

934

935

936

937

938

939

940

941

942

943

944

945

946

947

948

949

950

951

952

953

954
Inglis, G.D., Kalischuk, L.D., Busz, H.W. 2003. A survey of Campylobacter species shed in faeces of beef cattle using polymerase chain reaction. Can. J. Microbiol. 49:655-661.

Inglis, G.D., Kalischuk, L.D., Busz, H.W. 2004. Chronic shedding of Campylobacter species in beef cattle. J. Appl. Microbiol. 97:410-420.

Inglis, G.D., Morck, D.W., McAllister, T.A., Entz, T., Olson, M.E., Yanke, L.J., Read, R.R. 2006. Temporal prevalence of antimicrobial resistance in Campylobacter spp. from beef cattle in Alberta feedlots. Appl. Environ. Microbiol.72:4088-4095

Inglis, G.D., Hoar, B.M., Whiteside, D.P., Morck, D.W. 2007. Campylobacter canadensis sp. nov., from captive whooping cranes in Canada. Int. J. Syst. Evol. Microbiol. 57:2636-2644.

Inglis, G.D., Boras, V.F., Houde, A. 2011. Enteric Campylobacteria and RNA Viruses Associated with Healthy and Diarrheic Humans in the Chinook Health Region of Southwestern Alberta, Canada. J. Clin. Microbiol. 49:209-219.

International Standard Organisation (ISO). 2006. Microbiology of food and animal feeding stuffs. Horizontal method for the detection and enumeration of Campylobacter spp.-- Part 1. Detection method. ISO/CD 10272-1-2006. AFNOR, Paris, France.

Iugovaz, .I, Poulin, N., Belanger, G., Boucher, F., Ouhna, K., Beloui, S., Plante, D., Trottier, Y.L., Carrillo, C. 2009. Prevalence of Campylobacter in Canadian retail poultry. Abstract in Proceedings of 2009 Federal Food Safety and Nutrition Research Meeting.

Jelinski, M.D., Ribble, C.S., Chirino-Trejo, M., Clark, E.D., Janzen, E.D. 1995. The relationship between the presence of Helicobacter pylori, Clostridiu perfringens type A, Campylobacter spp., or fungi and fatal abomasal ulcers in unweaned beef calves. Can. Vet. J. 36:379-382.

Johnson, P., Mahdi, A., Baker, T., Odumeru, J. 2003a. Microbiological analysis of raw beef carcasses in Ontario abattoirs - A summary report. Food Inspection Branch, Ontario Ministry of Agriculture and Food.

Johnson, P., Odumeru, J., Mahdi, A. 2003. EF5065: Final Research Report on Microbiological Baseline Survey of Provincially Inspected Meat and Poultry Processing Plants in Ontario. Food Inspection Branch, Ontario Ministry of Agriculture and Food.

Jokinen, C.J., Schreier, H., Mauro, W., Taboada, E., Isaac-Renton, J.L., Topp, E., Edge, T., Thomas J.E., Gannon, V.P.J. 2010. The occurrence and sources of Campylobacter spp., Salmonella enterica and Escherichia coli O157:H7 in the Salmon River, British Columbia, Canada. J Water Health. 8:374-386.

Jokinen, C.C., Koot J.M., Carrillo, C.D., Gannon, V.P.J., Jardine, C.M., Mutschall, S.K., Topp, E., Taboada, E.N. 2012. An enhanced technique combining pre-enrichment and passivefiltration increases the isolation efficiency of Campylobacter jejuni and Campylobacter coli from water and animal fecal samples. J. Microbiol. Methods. 91:506-513. 
Karmali, M.A., Penner, J.L., Fleming, P.C., Williams A., Hennessy, J.N. 1983.The serotype and biotype distribution of clinical isolates of Campylobacter jejuni and Campylobacter coli over a three-year period. J. Infect. Dis. 147:243-246.

Keegan, V.A., Majowicz, S.E., Pearl, D.L., Marshall, B.J., Sittler, N., Knowles, L., Wilson, J.B. 2009. Campylobacter, verotoxigenic E. coli and Shigella, from 2000 to 2004; Epidemiology of enteric disease in C-EnterNet's pilot site - Waterloo region, Ontario, 1990 to 2004. Can. J. Infect. Dis. Med. Microbiol. 20:79-87.

Khan, I.U., Gannon, V., Loughborough, A., Jokinen, C., Kent, R.,Koning, W., Lapen, D.R., Medeiros, D., Miller, J., Neumann, N., Phillips, R., Robertson, W., Schreier, H., Topp, E., van Bochove, E., Edge, T.A. 2009. A methods comparison for the isolation and detection of thermophilic campylobacters in agricultural watersheds. J. Microbiol. Methods. 79:307-313.

Khan, I.U.H., Hill, S., Nowak, E., Palmer, M.E., Jarjanazi, H., Lee, D-Y., Mueller, M., Schop, R., Weir, S., Abbey, A-M.I., Winter, J., Edge, T.A. 2013a. Investigation of the prevalence of thermophilic Campylobacter species at Lake Simcoe recreational beaches. Inland Waters. 3:93104.

Khan, I.U.H., Hill, S., Nowak, E., Edge, T.A., 2013b. Effect of incubation temperature on the detection of thermophilic Campylobacter species from freshwater beaches, and nearby wastewater effluents and bird fecal droppings. Appl. Environ. Microbiol. 79:7639-7645.

Khan, I.U.H., Gannon, V., Jokinen, CC., Kent, R., Koning, W.,Lapen, DR., Medeiros, D., Miller, J., Neumann, NF., Phillips, R., Schreier, H.,Topp, E., van Bochove, e., Wilkes, G., Edge. TA. 2014. A national investigation of the prevalence and diversity of thermophilic Campylobacter species in agricultural watersheds in Canada. Water Res. 61:243-252.

Kittl, S., Heckel, G., Korczak, B.M., Kuhnert, P. 2013. Source Attribution of Human Campylobacter Isolates by MLST and Fla-Typing and Association of Genotypes with Quinolone Resistance. PLoS ONE. 8: e81796. doi:10.1371/journal.pone.0081796.

Krause, M., Josefsen, M.H,, Lund, M., Jacobsen, N.R., Brorsen, L., Moos, M., Stockmarr, A., Hoorfar, J. 2006. Comparative, Collaborative, and On-Site Validation of a TaqMan PCR Method as a Tool for Certified Production of Fresh, Campylobacter-Free Chickens. Appl. Environ. Microbiol. 72:5463-5468.

1000

Kwan, P.S., Xavier, C., Santovenia, M,, Pruckler, J., Stroika, S., Joyce, K., Gardner, T., Fields, P..I, McLaughlin, J., Tauxe, R.V., Fitzgerald, C. 2014. Multilocus sequence typing confirms wild birds as the source of a Campylobacter outbreak associated with the consumption of raw peas. Appl. Environ. Microbiol. 80:4540-4546.

Lal, A., Hales, S., French, N., Baker, M. 2012. Seasonality in human zoonotic enteric diseases: a systematic review. PLOS One. 7: e31883. 
1001 Lammerding, A.M., Garcia, M.M., Mann, E.D., Robinson, Y., Dorward, W.J., Truscott, R.B., 1002 Tittiger, F. 1988. Prevalence of Salmonella and thermophilic Campylobacter in fresh pork, beef, 1003 veal and poultry in Canada. J. Food Prot. 5:47-52.

1004

1005

1006

1007

1008

1009

1010

1011

1012

1013

1014

1015

1016

1017

1018

1019

1020

1021

1022

1023

1024

1025

1026

1027

1028

1029

1030

1031

1032

1033

1034

1035

1036

1037

1038

1039

1040

1041

1042

1043

1044

Lastovica, A.J. 2006. Emerging Campylobacter spp.: The tip of the iceberg. Clin. Microbiol. Newsletter. 28:49-56.

Lefebvre, B., Malouin, F., Roy, G., Giguere, K., Diarra, M.S. 2006a. Growth performance and shedding of some pathogenic bacteria in feedlot cattle treated with different growth-promoting agents. J. Food Prot. 69:1256-1264.

Lefebvre, S.L., Waltner-Toews D., Peregrine, A.S., Reid-Smith, R., Hodge, L., Arroyo, L.G., Weese, J.S. 2006b. Prevalence of zoonotic agents in dogs visiting hospitalized people in Ontario: implications for infection control. J. Hosp. Infect. 62:458-466.

Leonard, E.K., Pearl, D.L., Janecko, N., Weese, J.S., Reid-Smith, R.J., Peregrine, A.S., Finley, R.L. 2011. Factors related to Campylobacter spp. carriage in client-owned dogs visiting veterinary clinics in a region of Ontario, Canada. Epidemiol. Infect. 139:1531-1541.

Lévesque, B., Gagnon, F., Valentin, A., Cartier, J.F., Chevalier, P., Cardinal, P., Cantin, P.,Gingras, S. 2006. A study to assess the microbial contamination of Mya arenaria clams from the north shore of the St Lawrence River estuary, (Québec, Canada). Can. J. Microbiol. 52:984-991.

Lévesque, S., Fournier, E., Carrier, N., Frost, E., Arbeit, R.D., Michaud, S. 2013.

Campylobacteriosis in urban versus rural areas: a case-case study integrated with molecular typing to validate risk factors and to attribute sources of infection. PLoS ONE 8: 83731.

doi:10.1371/journal.pone.0083731.

Li, L., Mendis, N., Trigui, H., Oliver, J.D., Faucher, S.P. 2014. The importance of the viable but non-culturable state in human bacterial pathogens Front. Microbiol.doi: 10.3389/fmicb.2014.00258.

Lior, H., Woodward, D. L., Edgar, J.A., Laroche, L. J., Gill, P. 1982. Serotyping of Campylobacter jejuni by slide agglutination based on heat-labile antigenic factors. J. Clin. Microbiol. 15:761-768.

Magajna, B.A., Schraft, H. 2015. Campylobacter jejuni biofilm cells become viable but nonculturable (VBNC) in low nutrient conditions at $4{ }^{\circ} \mathrm{C}$ more quickly than their planktonic counterparts. Food Control. 50:45-50.

Mafu, A. A., R. Higgins, M. Nadeau, and G. Cousineau. 1989. The incidence of Salmonella, Campylobacter, and Yersinia enterocolitica in swine carcasses and the slaughterhouse environment. J. Food Prot. 52:642-645.

Mandrell, R.E., Miller, W.G. 2006. Campylobacter. In: Motarjemi, Y., Adams, M. (Eds), Emerging Foodborne Pathogens. Woodhead Publishing Limited, Cambridge, England, pp. 476-520. 
1045 McMyne, P.M., Penner, J.L., Mathias, R.G., Black, W.A., Hennessy, J.N. 1982. Serotyping of 1046 Campylobacter jejuni isolated from sporadic cases and outbreaks in British Columbia. J. Clin.

1047 Microbiol. 16:281-285.

1048

1049

1050

1051

1052

1053

1054

1055

1056

1057

1058

1059

1060

1061

1062

1063

1064

1065

1066

1067

1068

1069

1070

1071

1072

1073

1074

1075

1076

1077

1078

1079

1080

1081

1082

1083

1084

1085

1086

1087

1088

1089

McNaughton, R.D., Leyland, R., Mueller, L. 1982. Outbreak of Campylobacter enteritis due to consumption of raw milk. Can. Med. Assoc. J. 126:657-658.

Michaud, S., Ménard, S., Arbeit, R.D. 2004. Campylobacteriosis, Eastern Townships, Quebec. Emer. Infect. Dis. 10:1844-1847.

Medeiros, D.T., Sattar, S.A., Farber, J.M, Carrillo, C.D. 2008. Occurrence of Campylobacter spp. in raw and ready-to-eat foods and in a Canadian food service operation. J. Food Prot. 71:20872093.

Millson, M., Bokhout, M., Carlson, J., Spielberg, L., Aldis, R., Borczyk, A.,Lior, H. 1991. An outbreak of Campylobacter jejuni gastroenteritis linked to meltwater contamination of a municipal well. Can. J. Pub. Health. 82:27-31.

Ministry of Ontario Agriculture, Food and Rural Affairs, 2004. Food Safety Research Program Project Summaries 2004: SF6038 - Prevalence and Enumeration of Foodborne Microbial Hazards in Retail Raw Meat Products in an Ontario Community. Available at:

http://www.omafra.gov.on.ca/english/research/foodsafety/2004/sf6038.htm. Last accessed: October $15,2013$.

Moore, J.E., Corcoran, D., Dooley, J.S.,Fanning, S., Lucey, B., Matsuda, M., McDowell, D.A., Mégraud, F., Millar, B.C., O'Mahony, R., O'Riordan, L., O'Rourke, M., Rao, J.R., Rooney, P.J., Sails, A., Whyte, P. 2005. Campylobacter. Vet. Res. 36:351-382.

Munroe, D.L., Prescott, J.F., Penner, J.L. 1983. Campylobacter jejuni and Campylobacter coli serotypes isolated from chickens, cattle, and pigs. J. Clin. Microbiol. 18:877-881.

Nadeau, E., Messier, S., Quessy, S. 2002. Prevalence and comparison of genetic profiles of Campylobacter strains isolated from poultry and sporadic cases of campylobacteriosis in humans. J. Food Prot. 65:73-78.

Ng, L.K., Stiles, M.E., Taylor, D.E. 1985. Inhibition of Campylobacter coli and Campylobacter jejuni by antibiotics used in selective growth media. J. Clin. Microbiol. 22:510-514.

Ng, L.K., Taylor, D.E., Stiles, M.E. 1988. Characterization of freshly isolated Campylobacter coli strains and suitability of selective media for their growth. J. Clin. Microbiol. 26:518-523.

Oliver, J.D. 2010. Recent findings on the viable but nonculturable state in pathogenic bacteria. FEMS Microbiol Rev. 34:415-425.

Park, C.E., Stankiewicz, Z.K., Lovett, J., Hunt, J.1981. Incidence of Campylobacter jejuni in fresh eviscerated whole market chickens. Can. J. Microbiol. 27:841-842. 
Park, C.E., Stankiewicz, Z.K., Lovett, J., Hunt, J., Francis, D.W. 1983. Effect of temperature, duration of incubation, and $\mathrm{pH}$ of enrichment culture on the recovery of Campylobacter jejuni from eviscerated market chickens. Can. J. Microbiol. 29:803-806.

Park, C.E., Sanders, G.W. 1992. Occurrence of thermotolerant campylobacters in fresh vegetables sold at farmers' outdoor markets and supermarkets. Can. J. Microbiol. 38:313-316.

Penner, J. L., Hennessy, N. 1980. Passive haemagglutination technique for serotyping 12:732-737.

Pena, L.A., Fishbein, M.C. 2007. Fatal myocarditis related to Campylobacter jejuni infection: a case report. Cardiovascular Path. 16:119-121.

Prescott, J.F., Gellner, O.S. 1984. Intestinal carriage of Campylobacter jejuni and Salmonella by chicken flocks at slaughter. Can. J. Comp. Med. 48:329-331.

Pritchard, J., Osei-Applah, J., Zabec, E., Schimpl, T., Yoon, Y., Robertson, J. 2006. Baseline prevalence of Campylobacter jejuni and Campylobacter coli in broiler flocks and dairy herds in the Lower Fraser Valley of British Columbia (BC) Canada, 2005-2006. Proceedings of 2006 Canadian campylobacter conference, Vancouver, BC, Canada, page18.

1124

1125 J.S., Peregrine, A.S., Sargeant, J.M. 2014. A cross-sectional study examining Campylobacter and other zoonotic enteric pathogens in dogs that frequent dog parks in three cities in south-western Ontario and risk factors for shedding of Campylobacter spp. Zoonoses Public Health. 61:208-218.

Public Health Agency of Canada. 2000. Waterborne outbreak of gastroenteritis associated with a contaminated municipal water supply, Walkerton, Ontario, May-June 2000. Canadian Communicable Disease Report, 26, 20. http://www.phac-aspc.gc.ca/publicat/ccdrrmtc/00vol26/dr2620eb.html. Last updated: 2002-11-08.

Public Health Agency of Canada. 2006. C-EnterNet 2006 Annual Report. http://publications.gc.ca/collections/collection_2008/phac-aspc/HP37-8-2007E.pdf

Public Health Agency of Canada. 2007. C-EnterNet 2007 Annual Report.

http://publications.gc.ca/collections/collection_2012/aspc-phac/HP37-8-2007-1-eng.pdf.

Public Health Agency of Canada. 2008. C-EnterNet 2008 Annual Report. http://www.phacaspc.gc.ca/c-enternet/pubs/2008/campylobacter-eng.php.

1135 Campylobacter, verotoxigenic E. coli and Shigella, from 2000 to 2004. Can. Comm. Dis. Rep. 35S3:1-50. 
1136 Public Health Agency of Canada. 2009b. C-EnterNet 2009 Annual Report.

1137

1138

1139

1140

1141

1142

1143

1144

1145

1146

1147

1148

1149

1150

1151

1152

1153

1154

1155

1156

1157

1158

1159

1160

1161

1162

1163

1164

1165

1166

1167

1168

1169

1170

1171

1172

1173

1174

1175

1176

1177

1178

1179

1180 http://www.phac-aspc.gc.ca/c-enternet/pubs/2009/ch03-eng.php\#b34.

Public Health Agency of Canada, 2010. National Integrated Enteric Disease Surveillance Program. Sample Collection, Preparation \& Laboratory Methodologies. http://www.phac-aspc.gc.ca/centernet/pdf/lab_sop-eng.pdf.

Public Health Agency of Canada - NESP. 2011a. National Enteric Surveillance Program (NESP). http://www.nml-lnm.gc.ca/NESP-PNSME/index-eng.htm.

Public Health Agency of Canada. 2014. FoodNet Canada (formerly known as C-EnterNet). http://www.phac-aspc.gc.ca/foodnetcanada/index-eng.php.

Public Health Agency of Canada. 2011c. Canadian Integrated Program for Antimicrobial Resistance Surveillance (CIPARS) Reports. http://www.phac-aspc.gc.ca/cipars-picra/indexeng.php.

Public Health Agency of Canada. 2011d. d -EnterNet Annual Report 2006, 2007, 2008 and 2009(short report). http://www.phac-aspc.gc.ca/c-enternet/publications-eng.php.

Quessy, S., Messier, S. 1992. Prevalence of Salmonella spp., Campylobacter spp. and Listeria spp. in ring-billed gulls (Larus delawarensis). J. Wild. Dis. 28:526-531.

Rajda, Z., Middleton, D. 2006. Descriptive epidemiology of enteric illness for selected reportable diseases in Ontario, 2003. Can. Comm. Dis. Rep. 32:275-285.

Raji c A, Waddell LA, Sargeant JM, ReadS, Farber J, Firth MJ, Chambers A. 2007. An overview of microbial food safety programs in beef, pork, and poultry from farm to processing in Canada. J Food Prot. 70:1286-94.

Ravel, A., Greig, J., Tinga, C., Todd, D., Campbell, G., Cassidy, M., Marshall, B., Pollari, F. 2009. Exploring historical Canadian foodborne outbreak data sets for human illness attribution. J. Food Prot.72:1963-1976.

Rees, J.H., Soudain, S.E., Gregson, N.A., Hughes, R.A. 1995. Campylobacter jejuni infection and Guillain-Barré Syndrome. New Eng. J. Med. 333:1374-1379.

Ruzante, J.M., Majowicz, S.E., Fazil, A., Davidson, V.J. 2011. Hospitalization and deaths for select enteric illnesses and associated sequelae in Canada, 2001-2004. Epidemiol. Infect.139:937-945.

Schmidt, P.J., Pintar, K.D.M., Fazil, A.M., Flemming, C.A., Lanthier, M., Laprade, N., Sunohara, M.D., Simhon, A. Thomas, J.L., Topp, E., Wilkes, G., Lapen, D.R. 2013. Using Campylobacter spp. and Escherichia coli data and Bayesian microbial risk assessment to examine public health risks in agricultural watersheds under tile drainage management. Water Res. 47:3255- 3272. 
1181 Schuster, C.J., Ellis, A.G., Robertson, W.J., Charron, D.F., Aramini, J.J., Marshall, B.J., Medeiros, 1182 D.T. 2005. Infectious disease outbreaks related to drinking water in Canada, 1974-2001. Can. J.

1183 Pub. Health. 96:254-258.

1184

1185

1186

1187

1188

1189

1190

1191

1192

1193

1194

1195

1196

1197

1198

1200

1201

1202

1203

1204

1205

1206

1207

1208

1209

1210

1211

1212

1213

1214

1215

1216

1217

1218

1219

1220

1221

1222

1223

1224

1225

1226
Scott, L., Menzies, P., Reid-Smith, R.J., Avery, B.P., McEwen, S.A., Moon, C.S., Berke, O.. 2012. Antimicrobial resistance in Campylobacter spp. isolated from Ontario sheep flocks and associations between antimicrobial use and antimicrobial resistance. Zoonoses Public Health. 59:294-301.

Shanker, S, Lee, A., Sorrell, T.C. 1990. Horizontal transmission of Campylobacter jejuni amongst broiler chicks: experimental studies. Epidemiol. Infect. 104:101-110.

Simor, A.E., Karmali, M.A., Jadavji, T., Roscoe, M. 1986. Abortion and perinatal sepsis associated with Campylobacter infection. Rev. Inf. Dis. 8:397-402.

Skirrow MB. 1977. Campylobacter enteritis: a "new disease”. Brit. Med. J. 2:9-11.

Skirrow, M.B. 2006. John McFadyean and the centenary of the first isolation of Campylobacter species. Clin. Inf. Dis. 43:1213-1217.

Schmidt, P.J., Pintar, K.D.M., Fazil, A.M., Flemming, C.A., Lanthier, M., Laprade, N., Sunohara, M.D., Simhon, A., Thomas, J.L., Topp, E., Wilkes, G., Lapen, D.R. 2013. Using Campylobacter spp. and Escherichia coli data and Bayesian microbial risk assessment to examine public health risks in agricultural watersheds under tile drainage management. Water Res. 47:3255-3272.

Silva, J., Leite, D., Fernandes, M., Mena, C, Gibbs, P.A.,Teixeira, P. 2011._Campylobacterspp.as a foodborne pathogen:a review. Front. Microbiol. 2:200.

Steele, M.L., McNab, W.B., Poppe, C., Griffiths, M.W., Chen, S., Degrandis, S.A., Fruhner, L.C., Larkin, C.A., Lynch. J.A., Odumeru, J.A. 1997. Survey of Ontario bulk tank raw milk for foodborne pathogens. J. Food Prot. 60:1341-1346.

St-Pierre, K., Lévesque, S., Frost, E., Carrier, N., Arbeit, R.D., Michaud, S. 2009. Thermotolerant coliforms are not a good surrogate for Campylobacter spp. in environmental water. Appl. Environ. Microbiol. 75:6736-44.

Stuart, T.L., Sandhu, J., Stirling, R., Corder, J., Ellis, A., Misa, P., Goh, S., Wong, B., Martiquet, P., Hoang, L., Galanis, E. 2010. Campylobacteriosis outbreak associated with ingestion of mud during a mountain bike race. Epidemiol. Infect.138:1695-1703.

Sutherland, S.J., Gray, J.T., Menzies, P.I., Hook, S.E., Millman, S.T. 2009. Transmission of foodborne zoonotic pathogens to riparian areas by grazing sheep. Can. J. Vet. Res. 73:125-131.

Suzuki, H., Yamamoto, S. 2009. Campylobacter contamination in retail poultry meats and byproducts in the World: A literature survey. J. Vet. Med. Sci. 71: 255-261. 
1227 Taboada, E.N., Ross, S.L., Mutschall, S.K., Mackinnon, J.M., Roberts, M.J., Buchanan, C.J., 1228 Kruczkiewicz, P., Jokinen, C.C., Thomas, J.E., Nash, J.H., Gannon, V.P., Marshall, B., Pollari, F., 1229 Clark, C.G. 2012. Development and validation of a comparative genomic fingerprinting method for

Taboada, E.N., Clark, C., Sproston, E.L., Carrillo, C.D. 2013. Current Methods for Molecular Typing of Campylobacter species. J. Microbiol. Methods. 95:24-31.

Taylor, E.V., Herman, K.M., Ailes, E.C., Fitzgerald, C., Yoder, J.S., Mahon, B.E., Tauxe, R.V. 2013. Common source outbreaks of Campylobacter infection in the USA, 1997-2008. Epidemiol Infect.141:987-96.

Thibodeau, A., Fravalo, P., Laurent-Lewandowski, S., Guévremont, E., Quessy, S., Letellier, A. 2011. Presence and characterization of Campylobacter jejuni in organically raised chickens in Quebec. Can. J. Vet. Res. 75:298-307.

Thomas, MK., Murray, R., Flockhart, L., Pintar, K., Pollari, F., Fazil, A., Nesbitt, A., Marshall, B. 2013. Estimates of the burden of foodborne illness in Canada for 30 specified pathogens and unspecified agents, circa 2006. Foodborne Pathog Dis. 10:639-648.

Thomas, K.M., Charron, D.F., Waltner-Toews, D., Schuster, C., Maarouf, A.R., Holt, J.D. 2006. A role of high impact weather events in waterborne disease outbreaks in Canada, 1975 - 2001. Int. J. Environ. Health Res. 16:167-180.

Thomas, M.K., Majowicz, S.E., Pollari, F., Sockett, P.N. 2008. Burden of acute gastrointestinal illness in Canada, 1999-2007: interim summary of NSAGI activities. Can. Comm. Dis. Rep. 34:815.

Thompson, J. S., Cahoon, F.E., Hodge, D.S. 1986. Rate of Campylobacter spp. isolation in three regions of Ontario, Canada, from 1978 to 1985. J. Clin. Microbiol. 24:876-878.

Tustin, J., Laberge, K., Michel, P., Reiersen, J., Daadadottir, S., Briem, H., Hardardottir, H., Kristinsson, K., Gunnarsson, E., Fridriksdottir, V., Georgsson, F. 2011. A National Epidemic of Campylobacteriosis in Iceland,Lessons Learned. Zoonoses Public Health. 58:440-447

United States Department of Agriculture, 2014. MLG 41.03: Isolation, Identification and Enumeration of Campylobacter jejuni/coli/lari from Poultry Rinse, Sponge and Raw Product Samples. http://www.fsis.usda.gov/wps/wcm/connect/0273bc3d-2363-45b3-befb1190c25f3c8b/MLG-41.pdf?MOD=AJPERES

United States Department of Food and Drug Administration. 2001. Bacteriological Analytical Manual, Chapter 7, Campylobacter. http://www.cfsan.fda.gov/ ebam/bam-7.html.

United States Department of Agriculture (USDA), Food Safety and Inspection Service (FSIS). 2008. The Nationwide Microbiological Baseline Data Collection Program: Young Chicken Survey: 
1272

1273

1274

1275

1276

1277

1278

1279

1280

1281

1282

1283

1284

1285

1286

1287

1288

1289

1290

1291

1292

1293

1294

1295

1296

1297

1298

1299

1300

1301

1302

1303

1304

1305

1306

1307

1308

1309

1310

1311

1312

1313

1314

1315

1316

July 2007- June 2008. http://www.fsis.usda.gov/wps/wcm/connect/deab6607-f081-41a4-90bf8928d7167a71/Baseline_Data_Young_Chicken_2007-2008.pdf?MOD=AJPERES

United States Department of Agriculture (USDA). 2010. New Performance Standards for Salmonella and Campylobacter in Young Chicken and Turkey Slaughter Establishments; New Compliance Guides. Federal Register / Vol. 75, No. 93 / Friday, May 14, 2010 / Notices. http://www.fsis.usda.gov/OPPDE/rdad/FRPubs/2009-0034.pdf

USDA. 2012. The Nationwide Microbiological Baseline Data Collection Program: Raw Chicken Parts Survey 2012. http://www.fsis.usda.gov/shared/PDF/Baseline_Data_Raw_Chicken_Parts.pdf

United States Department of Agriculture, 2014. MLG 41.03: Isolation and Identification Campylobacter jejuni/coli/lari from Poultry Rinse, Sponge and Raw Product Samples. http://www.fsis.usda.gov/wps/wcm/connect/0273bc3d-2363-45b3-befb-1190c25f3c8b/MLG41.pdf?MOD=AJPERES

Valdivieso-Garcia, A., Harris, K., Riche, E., Campbell, S., Jarvie, A., Popa, M., Deckert, A., ReidSmith, R., Rahn, K.J. 2007. Novel Campylobacter isolation method using hydrophobic grid membrane filter and semisolid medium. J. Food Prot. 70:355-362.

Van Donkersgoed, J.V., Janzen, E., Schumann, F., Clark, E.G., Orr, J., Copeland, S., Chirino-Trejo, M., Berry, C., Spinato, M. 1989. Saskatchewan. Campylobacter jejuni abortion in beef cattle. Can. Vet. J. 30:680.

Van Donkersgoed, J., Janzen, E.D., Chirino-Trejo, M., Dunn, C. 1990a. Prevalence of Campylobacter jejuni in pronghorns and mule deer in southern Saskatchewan. Can. Vet. J. 31:302303.

Van Donkersgoed, J., Janzen, E.D., Chirino-Trejo, M., Berry, C., Clark, E.G., Haines, D.M. 1990 b. Campylobacter jejuni abortions in two beef cattle herds in Saskatchewan. Can.Vet. J. 31:373-377.

Van Donkersgoed, J., Bohaychuk, V., Besser, T., Song, X.M., Wagner, B., Hancock, D., Renter, D., Dargatz, D. 2009. Occurrence of foodborne bacteria in Alberta feedlots. Can. Vet. J. 50:166172.

Van Dyke, M.I., Morton, V.K., McLellan, N.L., Huck, P.M. 2010. The occurrence of Campylobacter in river water and waterfowl within a watershed in southern Ontario, Canada. J. Appl. Microbiol. 109:1053-1066.

Varela, N.P., Friendship, R.M., Dewey, C.E. 2007. Prevalence of Campylobacter spp. isolated from grower-finisher pigs in Ontario. Can. Vet. J. 48:515-517.

Verhoeff-Bakkenes, L., Jansen, H.A., in 't Veld, P.H., Beumer, R.R., Zwietering, M.H., van Leusden, F.M. 2011. Consumption of raw vegetables and fruits: a risk factor for Campylobacter infections. Int. J. Food Microbiol. 144:406-412. 
1317 Wagenaar, J.A., French, N.P., and Havelaar, A.H. 2013. Preventing Campylobacter at the Source: 1318 Why Is It So Difficult? Clin Infect Dis. DOI: 10.1093/cid/cit555.

Waltner-Toews, D., Martin, S.W., Meek, A.H. 1986. An epidemiological study of selected calf pathogens on Holstein dairy farms in southwestern Ontario. Can. J. Vet. Res. 50:307-13.

1325

Whiley, H., van den Akker, B., Giglio, S., Bentham, R. 2013. The Role of Environmental Reservoirs in Human campylobacteriosis. Int. J. Environ. Res. Public Health. 10:5886-5907.

Wilkes,G., Edge, T., Gannon, V., Jokinen, C., Lyautey, E., Medeiros, D., Neumann, N., Ruecker, N., Topp, E., Lapen, D.R. 2009. Seasonal relationships among indicator bacteria, pathogenic bacteria, Cryptosporidium oocysts, Giardia cysts, and hydrological indices for surface waters within an agricultural landscape. Water Res. 43:2209-2223.

White, P.L., Baker, A.R., James, W.O. 1997. Strategies to control Salmonella and Campylobacter in raw poultry products. Rev. Sci. Tech. 16:525-541.

Wingstrand, A., Neimann, J., Engberg, J., Nielsen, E.M., Gerner-Smidt,P.,Wegener, H.C., Molbak, K. 2006. Fresh chicken as main risk factor for campylobacteriosis, Denmark. Emerg. Infect. Dis. 12:280-5 
Table 1. Prevalence and culture procedures used in detection of campylobacters in samples from cattle.

\begin{tabular}{|c|c|c|c|c|c|c|}
\hline \multicolumn{2}{|l|}{ Sample type } & Number of Samples & Province $^{\mathrm{a}}$ & Test method & Prevalence $\%$ & Reference \\
\hline \multicolumn{2}{|l|}{ Feces or intestinal } & 412 & $\mathrm{ON}$ & Direct plating & 19 & Munroe et al., 1983 \\
\hline \multicolumn{2}{|l|}{ Tissues } & 525 & $\mathrm{ON}$ & Enrichment & 50 & Garcia et al., 1985 \\
\hline \multicolumn{2}{|c|}{ Feces } & 78 (farms) & $\mathrm{ON}$ & Direct plating (unknown agar) & 13 & Waltner-Toews et al., 1986 \\
\hline \multicolumn{2}{|c|}{ Neck muscle, gallbladder } & 666 (beef), 267 (veal) & National & Enrichment & 22.6 (beef), 43.1 (veal) & Lammerding et al., 1988 \\
\hline \multirow{2}{*}{$\begin{array}{l}\text { Samples ( } 8 \text { herds } \\
\text { with abortions) }\end{array}$} & Fetus \& placenta & $120 \& 108$ & SK & Direct plating & $10-19^{\mathrm{b}}$ & Van Donkersgoed et al., 1990b \\
\hline & Feces & $19-140$ & & & $0-50^{\mathrm{b}}$ & \\
\hline \multirow{3}{*}{\multicolumn{2}{|c|}{$\begin{array}{l}\text { Abomasal tissues } \\
\text { Feces } \\
\text { Feces }\end{array}$}} & 30 & SK & Direct plating & 20 & Jelinski et al., 1995 \\
\hline & & 382 & $\mathrm{AB}$ & Conventional and nested PCR & 83 & Inglis et al., 2003 \\
\hline & & 299 & $\mathrm{AB}$ & Nested Real-time PCR ${ }^{\mathrm{c}}$ & 90 & Inglis et al., 2004 \\
\hline \multicolumn{2}{|l|}{ Feces } & 7738 & $\mathrm{AB}$ & Direct plating & 20.5 & Inglis et al., 2006 \\
\hline \multicolumn{2}{|l|}{ Feces } & 50 (pooled) & $\mathrm{BC}$ & Enrichment & $60-80$ & Pritchard et al., 2006 \\
\hline \multicolumn{2}{|l|}{ Feces } & 80 & QC & Direct plating & 78.7 & Lefebvre et al., 2006 \\
\hline \multicolumn{2}{|c|}{ Feces } & 185 & QC & Nested PCR & 21.6 & Guévremont et al., 2008 \\
\hline \multicolumn{2}{|c|}{ Manure, carcass after HACCP } & $2100,1653^{d}$ & $\mathrm{AB}$ & Enrichment or filtration/plating & $76,0.06$ & Van Donkersgoed et al. 2009 \\
\hline \multirow{2}{*}{\multicolumn{2}{|c|}{$\begin{array}{l}\text { Fecal swabs } \\
\text { Feces } \quad \text { Dairy }\end{array}$}} & 2776 & $\mathrm{AB}$ & Direct plating & 87 & Hannon et al., 2009a \\
\hline & & $112-120(2006-2013){ }^{e, f}$ & $\mathrm{ON}$ & Enrichment $^{\mathrm{g}}$ & $21-82$ & C-EnterNet or FoodNet annual \\
\hline \multicolumn{2}{|c|}{ Beef } & $80-120(2007-2013)^{\mathrm{e}, \mathrm{f}}$ & & & $13-82$ & reports 2006-2013 \\
\hline
\end{tabular}

: ON=Ontario, $\mathrm{SK}=$ Saskatchewan, $\mathrm{AB}=\mathrm{Alberta}, \mathrm{BC}=$ British Columbia, $\mathrm{QC}=\mathrm{Quebec}$.

${ }^{b}$ : Range of prevalence between 8 herds.

c: Detection limit: $\approx 250 \mathrm{CFU} / \mathrm{g}$ of feces.

$\mathrm{d}$ : In the same order as samples.

e: Individual sample (Year).

f: 30 farms between 2010 and 2013 with prevalence of $97-100 \%$.

g. Detection limit: $0.3-10 \mathrm{CFU} / \mathrm{g}$. 
Table 2. Prevalence and culture procedures used in detection of campylobacters in samples from poultry.

\begin{tabular}{|c|c|c|c|c|c|}
\hline Sample type ${ }^{\mathrm{a}}$ & Number of sample & Province $^{b}$ & Test method & Prevalence $\%$ & Reference \\
\hline Feces or intestinal content & 398 & $\mathrm{ON}$ & Direct plating & 27.1 & Munroe et al., 1983 \\
\hline Cecal/cloccal of chicken, duck \& turkey & 235 & QC & Enrichment & 67.7 & Bourque, 1983 \\
\hline Colonic samples & 600 & $\mathrm{ON}$ & Direct plating & 46.7 & Prescot et al., 1984 \\
\hline Carcasses & 205 (turkey)/410 (broiler) & National & Enrichment & $73.7 / 38.2$ & Lammerding et al., 1988 \\
\hline Liver with or without necrotic hepatitis & 223 diseased, 50 normal & $\mathrm{QC}$ & Direct plating & 19.4 (21.1 abnormal livers; 12 normal livers) & Boukraa et al., 1991 \\
\hline Broiler chickens & 2325 & QC & Direct plating & 40 & Nadeau et al., 2002 \\
\hline Cecal samples & 450 flocks & $\mathrm{BC}$ & Direct plating & $5.6-88^{c}$ & Pritchard et al., 2006 \\
\hline Chickens and turkey cecal samples & 2430 & QC & Enrichment & 35.8 (chickens)/46 (turkey) & Arsenault et al., 2007a\&c \\
\hline Chicken \& turkey cecal samples & 2460 (chicken)/770 (turkey) & QC & Enrichment & $69.5 / 36.9$ & Arsenault et al., 2007b \\
\hline Carcass rinse & 1234 & $\mathrm{AB}$ & Enrichment & 75 & Bohaychuk et al., 2009 \\
\hline Cecal samples (organic farm) & 300 & QC & Direct plating & 50 & Thibodeau et al., 2011 \\
\hline Feces & $36-200(\text { year 2007-2013) })^{d}$ & $\mathrm{ON}, \mathrm{BC}$ & Enrichment & $0-46$ & PHAC FoodNet annual \\
\hline Turkey feces & $112(2013)^{\mathrm{e}}$ & $\mathrm{BC}$ & & 79 & reports 2006- 2013 \\
\hline
\end{tabular}

\footnotetext{
a: Chicken samples otherwise explained.

b: ON=Ontario, $\mathrm{QC}=$ Quebec, $\mathrm{BC}=$ British Columbia, $\mathrm{AB}=$ Alberta.

${ }^{\mathrm{c}}$ :Range of prevalence between 8 herds

d: ON (2007- 2013), BC (2013). 24-30 farms (ON, 2010-2013, BC, 2013) with prevalence of 7-42\%.

e: 28 farms with $82 \%$ prevalence.
} 
Table 3. Prevalence and procedures used to detect campylobacters in samples from pigs.

\begin{tabular}{|c|c|c|c|c|c|}
\hline Sample type & Number of sample & Province $^{\mathrm{a}}$ & Test method & Prevalence $\%$ & Reference \\
\hline Feces & 203 & $\mathrm{ON}$ & Direct plating & 58.1 & Munroe et al., 1983 \\
\hline Muscle (neck, diaphragm) \& feces & 666 & MA & Enrichment & 26.3 & Finlay et al., 1986 \\
\hline Neck muscle and gallbladder & 469 & National & Enrichment & 16.9 & Lammerding et al., 1988 \\
\hline Cecal sample & 109 & PEI & Direct plating & 72.5 & Hariharan et al., 1990 \\
\hline Rectal sample & 1200 & $\mathrm{ON}$ & Enrichment & 99 & Varela et al., 2007 \\
\hline Feces & 20 & QC & Conventional \& nested PCR & 25 & Guévremont et al., 2008 \\
\hline Feces (manure and individual) & $359 / 21$ & ON & Enrichment & $37 / 68$ & Farzan et al., 2010 \\
\hline Feces & $111-120 / 30(2006-2011)^{b c}$ & $\mathrm{ON}$ & Enrichment & $10-85 / 40-100^{c}$ & $\begin{array}{l}\text { FoodNet Canada annual } \\
\text { reports 2006-2011, PHAC }\end{array}$ \\
\hline Carcass swabs & 1070 & $\mathrm{AB}$ & Enrichment & 8.8 & Bohaychuk et a., 2011 \\
\hline
\end{tabular}

a : $\mathrm{ON}=$ Ontario, $\mathrm{MA}=$ Manitoba, $\mathrm{QC}=\mathrm{Quebec}, \mathrm{PEI}=$ Prince Edward Island, $\mathrm{AB}=$ Alberta.

${ }^{\mathrm{b}}$ : Individual/farm (year).

c: 2009 data is based on 2010 short report (2009 annual report was not complete for farm information). No test after 2011. 
Table 4. Prevalence and procedures used in detection of campylobacters in pets and wildlife.

\begin{tabular}{|c|c|c|c|c|c|}
\hline Sample type & Number of Sample & Province $^{\mathrm{a}}$ & Test method & Prevalence $\%$ & Reference \\
\hline Pronghorns and mule deer feces & 187 & SK & Enrichment & 0 & Van Donkersgoed et al., 1990a \\
\hline Cloacal swabs from ring-billed gulls & 264 & QC & Enrichment & 15.9 & Quessy and Messier, 1992 \\
\hline $\begin{array}{l}\text { Tree-nesting Double-crested cormorant chicks, } \\
\text { cloacal \& pharyngeal swabs }\end{array}$ & 100 & PEI & Direct plating & 22 & Dobbin et al., 2005 \\
\hline Shellfish (Whole clams) (Mya arenaria clams) & 72 & $\mathrm{QC}$ & $\begin{array}{l}\text { Conventional PCR/culture } \\
\text { confirmation }\end{array}$ & 47.2 & Lévesque et al., 2006 \\
\hline Whooping and sandhill cranes & 42 & $\mathrm{AB}$ & Direct plating & 5 & Hoar et a., 2007 \\
\hline $\begin{array}{l}\text { Captive adult whooping cranes (Grus americana) } \\
\text { Cloacal swabs }\end{array}$ & 10 & $\mathrm{AB}$ & Enrichment/PCR characterization & $\begin{array}{l}\text { Isolation of a new species: } C \text {. } \\
\text { canadensis sp. nov., }\end{array}$ & Inglis et al., 2007 \\
\hline $\begin{array}{l}\text { Dog fecal, hair, rectal, aural, nasal, oral \& } \\
\text { pharyngeal swabs }\end{array}$ & 102 & $\mathrm{ON}$ & Conventional PCR & 0 & Lefebvre et al., 2006. \\
\hline Waterfowl feces (seagulls, Canada geese, ducks) & 51 & $\mathrm{ON}$ & Enrichment/PCR & 29(culture)/ 32(PCR) & Van Dyke et al. 2010 \\
\hline Dog feces & 75 (healthy), 60 (diarrheic) & SK & Real-Time PCR & 58 healthy, 97 diarrheic & Chaban et al., 2010 \\
\hline Dog feces & 60 & SK & Real-time PCR & 75 & Himsworth et al., 2010 \\
\hline $\begin{array}{l}\text { Feces of dog, horse, llama, alpace, goose, duck, } \\
\text { rabbit, rat }\end{array}$ & $17,23,10,9,13,23,11,1^{\mathrm{b}}$ & $\mathrm{BC}$ & Enrichment/PCR identification & $\begin{array}{l}5.9,4.3,10,11.1,38.5,52.2 \\
0,0^{\mathrm{c}}\end{array}$ & Jokinen et al., 2010 \\
\hline Dog feces & 240 & $\mathrm{ON}$ & $\begin{array}{l}\text { Direct plating or Enrichment/PCR } \\
\text { identification }\end{array}$ & 22 & Leonard et al., 2011 \\
\hline Raccoon feces & 50 & $\mathrm{ON}$ & $\begin{array}{l}\text { Enrichment/plating } \pm \text { membrane } \\
\text { filtration. }\end{array}$ & 78 (76 with filtration) & Jokinen et al., 2012 \\
\hline Dog feces & 251 & $\mathrm{ON}$ & $\begin{array}{l}\text { Direct plating or Enrichment/PCR } \\
\text { identification }\end{array}$ & 43 & Procter et al., 2014 \\
\hline
\end{tabular}

${ }^{\mathrm{a}}$ : $\mathrm{SK}=$ Saskatchewan, $\mathrm{QC}=$ Quebec, $\mathrm{ON}=$ Ontario, $\mathrm{PEI}=$ Prince Edward Island, $\mathrm{AB}=\mathrm{Alberta}$.

${ }^{\mathrm{b}, \mathrm{c}}$ : numbers in the order as the order of sample types. 
Table 5. Prevalence and procedures used in detection of campylobacters in samples from water.

\begin{tabular}{|c|c|c|c|c|c|}
\hline Sample type & Number of sample & Province $^{\mathrm{a}}$ & Test method & Prevalence $\%$ & Reference \\
\hline Catch basin water & 21 (spring)/21/(fall) & $\mathrm{AB}$ & Enrichment & $52 / 0$ & Van Donkersgoed et al.,2009 \\
\hline Rivers and private surface wells & 2471 & QC & Enrichment or PCR \pm filtration & 43 & St-Pierre et al., 2009 \\
\hline Waterways water (sheep pasture) & 143 & $\mathrm{ON}$ & Enrichment/PCR confirmation & 14.7 & Sutherland et al., 2009 \\
\hline River water & 344 & $\mathrm{ON}$ & Enrichment/PCR & $0-23$ (culture)/57-79 by PCR & Van Dyke et al., 2010. \\
\hline River watershed water (4 sites) & 186 & $\mathrm{BC}$ & $\begin{array}{l}\text { Enrichment/PCR identification/RFLP } \\
\text { typing }\end{array}$ & $31.5-56.7$ & Jokinen et al., 2010 \\
\hline Water (title drainage) & 126 & $\mathrm{ON}$ & Filtration/MPN ${ }^{\mathrm{b}} / \mathrm{PCR}$ classification & $73(41-100)$ & Schmidt et al., 2013 \\
\hline Beach and river water & 389 & $\mathrm{ON}$ & MPN/PCR confirmation ${ }^{c}$ & 13 & Khan et al., 2013a \\
\hline $\begin{array}{l}\text { Water (Beach, offshore, } \\
\text { wastewater) }\end{array}$ & 597 & $\mathrm{ON}$ & $\begin{array}{l}\text { Centrifugation/enrichment/ } \\
\text { MPN/PCR confirmation }\end{array}$ & $61-63^{d}$ & Khan et al., 2013b \\
\hline \multirow[t]{2}{*}{ Agricultural surface water } & $699(2009)^{\mathrm{e}}$ & $\mathrm{AB}, \mathrm{BC}$ & filtration or centrifugation/enrichment & 49 (centrifugation)/33(filtration) & Khan et al., $2009 \& 2014$ \\
\hline & 769 (2014) & & $\begin{array}{l}\text { Semi-quantitative MPN/PCR } \\
\text { confirmation }\end{array}$ & $49^{\mathrm{f}}$ & \\
\hline Various types of water ${ }^{\mathrm{g}}$ & $20-134(2006-2013)$ & $\mathrm{ON}, \mathrm{BC}$ & Enrichment/quantitative $\mathrm{PCR}^{\mathrm{g}}$ & $9-52(58-92, \text { Molecular })^{h}$ & $\begin{array}{l}\text { FoodNet Canada annual } \\
\text { reports (2006-2013), PHAC }\end{array}$ \\
\hline
\end{tabular}

a : $\mathrm{AB}=$ Alberta, $\mathrm{QC}=$ Quebec, $\mathrm{ON}=$ Ontario, $\mathrm{BC}=$ British Columbia.

b: Practical upper and low detection limit: 1-2419 CFU/100 ml water (theoretical detection limit: $0.02 \mathrm{CFU} / 100 \mathrm{ml}$ ).

c; Generally $\leq 30$ cells per liter.

d: Results for incubation at $37^{\circ} \mathrm{C}$ which had higher prevalence than that incubated at $42^{\circ} \mathrm{C}$ (data not included).

e: (Year).

f: 4 - 4000 minimum probable number (MPN) cells per little $\left(\mathrm{L}^{-1}\right)$.

g. Untreated and recreational water for 2006-2013 in ON and BC depending on years, irrigation water in BC for 2013.

h: Quantitative PCR, referred as molecular test in the reference, was conducted for 2006 and 2007. 
Table 6. Prevalence and procedures used in detection of campylobacters in samples from raw and retail foods.

\begin{tabular}{|c|c|c|c|c|c|}
\hline Sample type & Number of samples & Province $^{\mathrm{a}}$ & Test method & Prevalence $\%$ & Reference \\
\hline \multicolumn{6}{|l|}{ Raw Meat } \\
\hline Chicken carcass & 500 & $\mathrm{ON}$ & Enrichment & 62 & Park et al., 1981 \\
\hline Chicken carcass & 150 & $\mathrm{ON}$ & Enrichment & 84 & Park et al., 1983 \\
\hline Chicken carcasses & 177 & QC & Centrifugation/enrichment & 23 & Michard et al., 2004 \\
\hline Chicken legs and wieners, turkey breast & $100,100 \& 101^{\mathrm{c}}$ & $\mathrm{AB}$ & Enrichment & 62 (chicken legs); 0 (rest) & Bohaychuk et al., 2006 \\
\hline Chicken \& turkey & 1200 (chicken), 454 (turkey) & $\mathrm{ON}$ & Filtration/enrichment & 45.8 (turkey), 62.4 (chicken) & Valdivieso-Garcia et al., 2007 \\
\hline Whole or parts of chicken and turkey & $51-78$ & Atlantic, QC, ON, BC & Enrichment & $30.3-49.2$ & Iugovaz et al., 2009 \\
\hline Chicken, Beef Liver & 55 & $\mathrm{ON}$ & Enrichment & 9.7 (chicken)/12.5 (beef liver) & Medeiros et al., 2008 \\
\hline Turkey & 412 & ON & Enrichment/plating+filtration & 46 & Cook et al., 2009 \\
\hline Chicken carcasses & 1256 & $\mathrm{ON}$ & Filtration/enrichment & 59.6 & Deckert et al., 2010 \\
\hline Veal (grain-fed) & 438 & $\mathrm{ON}$ & Enrichment/plating+filtration & 1 & Cook et al., 2011 \\
\hline Carcass swabs in slaughter $\quad$ Cattle & 1022 & $\mathrm{AB}$ & Enrichment & 1.5 & Bohaychuk et al., 2011 \\
\hline house cooler & 1070 & & & 8.8 & \\
\hline Turkey meat & 412 & $\mathrm{ON}$ & Enrichment/plating+filtration & 46 & Cook et al., 2012 \\
\hline Chicken meat & 348 & National & Enrichment/direct plating & 42.8 & Carrillo et al., 2014. \\
\hline Chicken Skin-on breast & $127-200(2006-2013)^{d}$ & $\mathrm{ON}, \mathrm{BC}$ & Enrichment & $31-51$ & FoodNet Canada annual \\
\hline Ground Chicken & $87-158(2011-2013)$ & & & $13-68$ & reports 2007-2013, PHAC \\
\hline Ground turkey & $96-155(2011)$ & & & $16-44$ & \\
\hline Frozen chicken nuggets & $24-129(2011-2013)$ & & & $0-59$ & \\
\hline Ground beef (not tested since 2011) & $187-200(2007-2010)$ & & & $1-2$ & \\
\hline Pork chop & $140-200(2006-2010)$ & & & $0-18$ & \\
\hline \multicolumn{6}{|l|}{ Ready-to-eat } \\
\hline Produce & 1564 & $\mathrm{ON}$ & Enrichment & $1.6-3.3$ in various vegetables ${ }^{b}$ & Park and Sanders, 1992 \\
\hline Meat, raw milk cheese, vegetable etc. & 261 & National & Enrichment & 0 & Medeiros et al., 2008 \\
\hline Fresh produce & 674 & $\mathrm{AB}$ & Enrichment & 0 & Bohaychuk et al., 2009 \\
\hline Leafy greens & $376(2009)$ & $\mathrm{ON}$ & Enrichment & 0 & $\begin{array}{l}\text { FoodNet Canada annual } \\
\text { reports 2007-2013, PHAC }\end{array}$ \\
\hline Produce (Market) & 410 & $\mathrm{ON}$ & Enrichment & 0 & Carrillo et al., 2013 \\
\hline
\end{tabular}


Table 7. Summary of culture media used in Canadian surveys.

\begin{tabular}{|c|c|c|c|c|c|}
\hline \multicolumn{3}{|l|}{ Direct plating } & \multicolumn{3}{|l|}{ Enrichment } \\
\hline Agar type & Number of studies & Frequency $(\%)$ & Broth type & Number of studies & Frequency $(\%)$ \\
\hline $\mathrm{mCCDA}^{\mathrm{a}}$ & 5 & $21.8^{b}$ & Bolton & 19 & 50 \\
\hline Campy-BAP ${ }^{\mathrm{c}}$ & 3 & 13 & Rosef & 6 & 15.8 \\
\hline Karmali & 3 & 13 & Park and Sanders & 6 & 15.8 \\
\hline Preston & 2 & 8.7 & Hunt & 3 & 7.9 \\
\hline Skirrow & 2 & 8.7 & Preston & 2 & 5.3 \\
\hline Muller-Hinton & 2 & 8.7 & Skirrow & 1 & 2.6 \\
\hline Columbia & 2 & 8.7 & Weybridge $^{\mathrm{d}}$ & 1 & 2.6 \\
\hline Campy-line & 1 & 4.3 & & & \\
\hline $\mathrm{MCBB}^{\mathrm{e}}$ & 1 & 4.3 & & & \\
\hline Weybridge $^{\mathrm{d}}$ & 1 & 4.3 & & & \\
\hline Unknown & 1 & 4.3 & & & \\
\hline Sub-total & $23^{f}$ & & & $38^{\mathrm{g}}$ & \\
\hline
\end{tabular}

a: Modified charcoal cefoperazone desoxycholate;

b: Approximate number due to the round-up;

c: Campylobcter agar with 5 antimicrobics and 10\% sheep blood;

d:Weybridge transportation and enrichment medium;

e: Modified Chocolate blood-based;

f: These are the numbers of agars used as primary isolation media, and there were also two additional agars used with enrichment broth in parallel with a total of 25 . To reflect the accurate numbers of surveys, 23 are used for this review;

g. These are the numbers of enrichment broth used as primary isolation media, and there were also two additional broth used with direct plating in parallel with a total of 41 . To reflect the accurate numbers of survey, 38 are used for this review. 